Prepared in cooperation with the Inyo County, California, Yucca Mountain Repository Assessment Office

\title{
Geologic Map of the southern Funeral Mountains including nearby Groundwater Discharge Sites in Death Valley National Park, California and Nevada
}

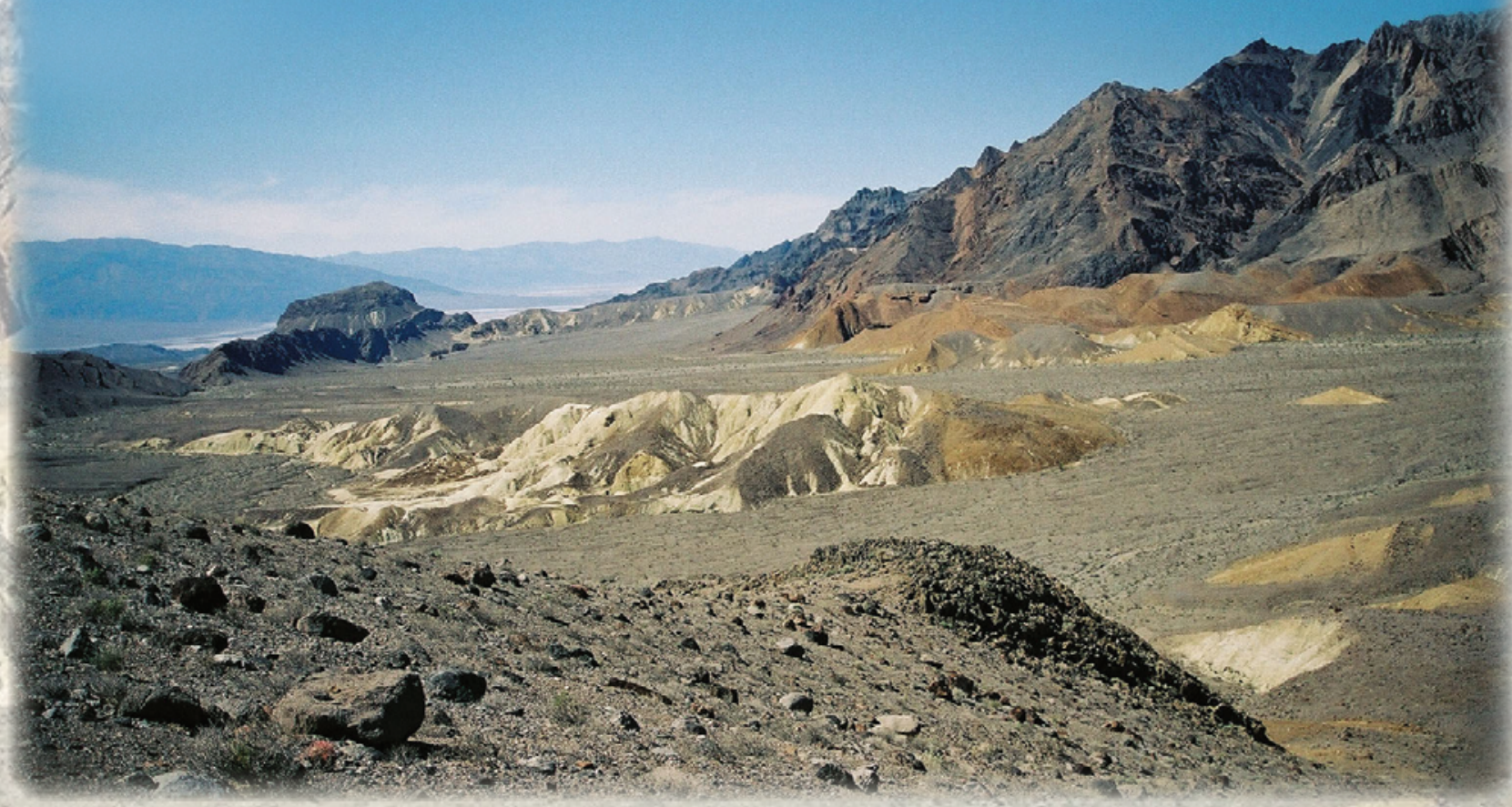

Pamphlet to accompany Scientific Investigations Map 3151

U.S. Department of the Interior U.S. Geological Survey 
Front cover. View looking northwest along the Furnace Creek fault zone in the vicinity of Hole-in-theWall (far left center) and Red Amphitheater canyon (to right of picture). Death Valley is visible in the distance, with the Panamint Range (left) and Cottonwood Mountains (center and more distant) on the skyline. Color change in low hills in the middle ground, from rusty orange (freshwater limestone; right) to light yellow (gypsum-bearing playa claystone; left) coincides with the major strand of the Furnace Creek fault in area of picture. Knobby dark outcrop in foreground is rock-avalanche breccia, which is capped by bouldery Pleistocene alluvium. Photograph taken by C.J. Fridrich, U.S. Geological Survey. 


\section{Geologic Map of the southern Funeral Mountains including nearby Groundwater Discharge Sites in Death Valley National Park, California and Nevada}

By C.J. Fridrich, R.A. Thompson, J.L. Slate, M.E. Berry, and M.N. Machette

Prepared in cooperation with the Inyo County, California,

Yucca Mountain Repository Assessment Office

Pamphlet to accompany Scientific Investigations Map 3151 


\title{
U.S. Department of the Interior \\ KEN SALAZAR, Secretary \\ U.S. Geological Survey \\ Marcia K. McNutt, Director
}

\author{
U.S. Geological Survey, Reston, Virginia: 2012
}

For more information on the USGS--the Federal source for science about the Earth, its natural and living resources, natural hazards, and the environment: visit http://www.usgs.gov or call 1-888-ASK-USGS

For an overview of USGS information products, including maps, imagery, and publications, visit http://www.usgs.gov/pubprod

To order this and other USGS information products, visit http://www.store usgs.gov

Any use of trade, product, or firm names is for descriptive purposes only and does not imply endorsement by the U.S. Government.

Although this report is in the public domain, permission must be secured from the individual copyright owners to reproduce any copyrighted materials contained within this report.

Suggested citation:

Fridrich, C.J., Thompson, R.A., Slate, J.L., Berry, M.E., and Machette, M.N., 2012, Geologic map of the southern Funeral Mountains including nearby groundwater discharge sites in Death Valley National Park, California and Nevada: U.S. Geological Survey Scientific Investigations Map 3151, 20 p. pamphlet, 1 sheet, scale 1:50,000. 


\section{Contents}

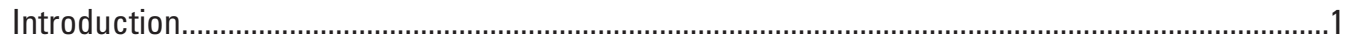

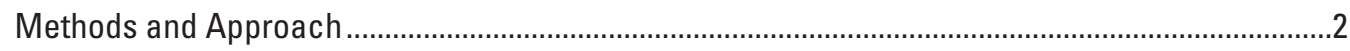

Geologic Summary and Interpretation of Cenozoic Tectonics......................................................

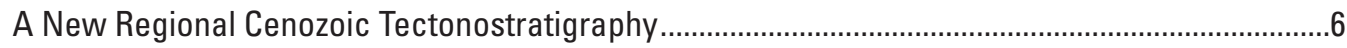

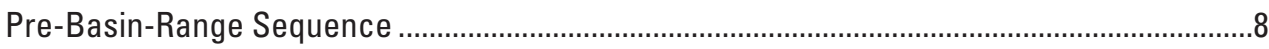

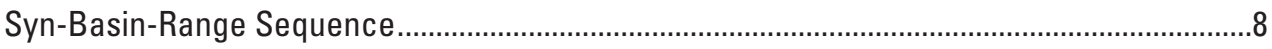

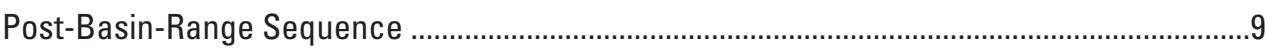

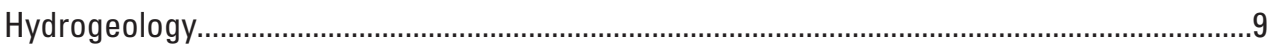

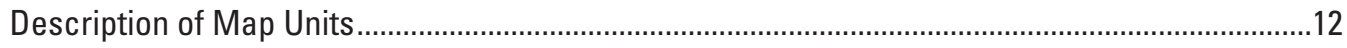

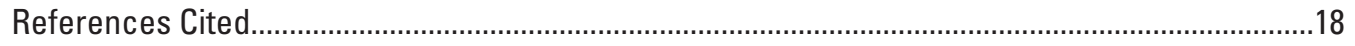

\section{Figures}

1. Landsat 7 satellite image of southern Funeral Mountains area, California and Nevada, showing location of map area and major physiographic features and structures. This image is a false-color composite, which combines bands 7 (SWIR, 2.09-2.35 $\mu \mathrm{m})$,

4 (near-IR, 0.77-0.90 $\mu \mathrm{m}$ ), and 2 (Green, 0.52-0.60 $\mu \mathrm{m}$ ) and displays them as red, blue, and green, respectively. Latitude and longitude ticks and scale are approximate see map sheet

2. Simplified geologic map showing major structures in the map area, along with key hydrogeologic features. Exposures of the different Cenozoic assemblages are shown along with ${ }^{40} \mathrm{Ar} /{ }^{39} \mathrm{Ar}$ age determinations

3. Hydrogeologic map showing the major springs of the Furnace Creek wash area, a modern seep, and adjacent Pleistocene groundwater discharge mound in the northeast part of map.

4. Four assemblages of syn-basin-range strata (Owlshead, Navadu, Furnace

Creek, and Badwater) were deposited during four stages of basin-range tectonism.

\section{Table}

1. List of key ${ }^{40} \mathrm{Ar} /{ }^{39} \mathrm{Ar}$ ages of Tertiary units in the southern Funeral Mountains, along with sample letters shown on simplified geologic map (map sheet, fig. 2), locations, and analysts 


\section{Conversion Factors and Datums}

\begin{tabular}{lcl}
\multicolumn{1}{c}{ SI to Inch/Pound } & & \\
\hline \multicolumn{1}{c}{ Multiply } & By & To obtain \\
\hline centimeter $(\mathrm{cm})$ & Length & \\
meter $(\mathrm{m})$ & 0.3937 & inch (in.) \\
kilometer $(\mathrm{km})$ & 3.281 & foot (ft) \\
\hline & 0.6214 & mile (mi) \\
\hline square kilometer $\left(\mathrm{km}^{2}\right)$ & Area & \\
\hline
\end{tabular}

Temperature in degrees Celsius $\left({ }^{\circ} \mathrm{C}\right)$ may be converted to degrees Fahrenheit $\left({ }^{\circ} \mathrm{F}\right)$ as follows: ${ }^{\circ} \mathrm{F}=\left(1.8 \mathrm{x}^{\circ} \mathrm{C}\right)+32$

Temperature in degrees Fahrenheit $\left({ }^{\circ} \mathrm{F}\right)$ may be converted to degrees Celsius $\left({ }^{\circ} \mathrm{C}\right)$ as follows: ${ }^{\circ} \mathrm{C}=\left({ }^{\circ} \mathrm{F}-32\right) / 1.8$

Vertical coordinate information is referenced to the National Geodetic Vertical Datum of 1929 (NGVD 29).

Horizontal coordinate information is referenced to the North American Datum of 1983 (NAD 83). Altitude, as used in this report, refers to distance above the vertical datum. 


\title{
Geologic Map of the southern Funeral Mountains including nearby Groundwater Discharge Sites in Death Valley National Park, California and Nevada
}

\author{
By C.J. Fridrich, R.A. Thompson, J.L. Slate, M.E. Berry, and M.N. Machette
}

\section{Introduction}

This 1:50,000-scale geologic map covers the southern part of the Funeral Mountains, and adjoining parts of four structural basins - Furnace Creek, Amargosa Valley, Opera House, and central Death Valley - in California and Nevada (map sheet, fig. 1). It extends over three full 7.5-minute quadrangles, and parts of eleven others - an area of about 1,000 square kilometers $\left(\mathrm{km}^{2}\right)$. The boundaries of this map were drawn to include all of the known proximal hydrogeologic features that may affect the flow of groundwater that discharges from springs of the Furnace Creek basin, in the westcentral part of the map (map sheet, fig. 2; fig. 3). These springs provide the main potable water supply for Death Valley National Park.

Major hydrogeologic features shown on this map include: (1) springs of the Furnace Creek basin, (2) a large Pleistocene groundwater discharge mound in the northeastern part of the map, (3) the exposed extent of limestones and dolomites that constitute the Paleozoic carbonate aquifer, and (4) the exposed extent of the alluvial conglomerates that constitute the Funeral Formation aquifer (map sheet, figs. 1 and 2). Notable features adjacent to the map area include: (1) the salt pans of Death Valley, immediately to the west and southwest (light blue on Landsat image base of figure 1), and (2) the springs at Ash Meadows, immediately to the east (green on Landsat image base of figure 1).

Geologic map data were used, along with measured formation thicknesses, to draw five geologic cross sections shown on map sheet. Two of these, $\boldsymbol{C}-\boldsymbol{C}^{\prime}$ and $\boldsymbol{E}-\boldsymbol{E}^{\prime}$, are drawn through the center of the map area, from southwest to northeast and from northwest to southeast, respectively, and best illustrate the large-scale structure. The other cross sections $\left(\boldsymbol{A}-\boldsymbol{A}^{\prime}, \boldsymbol{B}-\boldsymbol{B}^{\prime}\right.$, and $\left.\boldsymbol{D}-\boldsymbol{D}^{\prime}\right)$ were drawn to show the settings and context of important hydrologic exploration wells in the map area.

The map data and cross sections were used to generate a structure contour map on the base of the Paleozoic carbonate and Funeral Formation aquifer system in the southern Funeral Mountains and adjacent Furnace Creek basin (fig. 3). A preliminary version of this map was used as the basis for a computer model of the groundwater flow that feeds the Furnace Creek springs (Bredehoeft and others, 2005, 2008). It was also used as an input to the design of a drilling program conducted by the Inyo County (California) Yucca Mountain Repository Assessment Project. This project investigated interbasin flow under the southern Funeral Mountains as part of an assessment of the potential that radionuclides from the high-level nuclear waste repository proposed at Yucca Mountain, Nevada, could leak into and through the Paleozoic carbonate aquifer, to discharge from the Furnace Creek springs, about 50 kilometers $(\mathrm{km})$ southeast of the Yucca Mountain site.

The cross sections are simplified relative to the geologic map. These simplifications include lumping of map units into whole formations, and omission of many small faults and some surficial deposits. Additionally, numerous thin fault blocks of rocks caught up within the Funeral Mountains detachment fault zone are identified by formation on the geologic map, but are shown as fault breccia (Tnix) on the cross sections and on the simplified geologic map (map sheet, fig. 2). Thick fault zones that are an aggregate of numerous thin fault-block slivers are a form of megabreccia, even when the individual fault-block slivers are large enough to be mapped.

Few fault surfaces are directly measurable in the map area; hence, fault dips were derived mainly by photogrammetric mapping of the intersections of faults with topography. From the derived measurements, we draw two conclusions. First, in those parts of the map area where there is strong extension-related tilting, the major normal faults have moderate to low dips, such that fault-to-bedding angles are typically in the range of $60^{\circ}$ to $90^{\circ}$. Second, significant changes in dip are observable along many of the major faults, both laterally and vertically. We interpreted the latter observation as indicating that the majority of normal faults in the map area are at least moderately listric (concave upward), whereas a small minority of faults are antilistric (convex upward).

The cross sections are drawn to depths of about $1 \mathrm{~km}$ to slightly greater than $2 \mathrm{~km}$ because a major purpose of this study was to characterize the subsurface geometry of the Paleozoic carbonate aquifer, which locally is several kilometers thick. Geologic cross sections that project to these depths are inevitably quite interpretative, especially with respect to the subsurface geometry of the faults. To the extent possible, these interpretations are based on observed fault geometries, as previously discussed; however, the map data could be used to draw rather different cross-sectional geometries (for example, see Sweetkind and others, 2001). 
During an initial part of the study, different versions of the structure contour map on the base of the aquifer system were generated using a broad range of assumptions about the subsurface geometry of faults. The assumptions ranged from nearly planar faulting to listric fault geometries with much more rapid flattening with depth than in the preferred model (see cross sections on map sheet). The conclusion was that the hydrogeologic framework is not strongly dependent on the assumptions concerning subsurface fault geometry, except in the case of extreme assumptions that were deemed to be geologically implausible.

\section{Methods and Approach}

This study builds on previous bedrock maps (see index on map sheet) by McAllister (1970, 1971, 1973), Cemen (1983), and Wright and Troxel (1993). Whereas the previous maps cover much of the map area and the vast majority of the bedrock, the quality of these maps is best in certain focus areas, and generally diminishes toward the respective map boundaries. Throughout most of the map area, the previous bedrock mapping has been added to or revised based on extensive new fieldwork by Fridrich (from 2001 to 2005), Thompson (mainly from 1998 to 2002), and Machette (2002). Field maps were compiled using a photogrammetric stereoplotter and recent aerial photography. With few exceptions, the contacts on this new map are located photogrammetrically, in combination with GPS measurements taken in the field-tools that were unavailable to previous mappers.
During the previous mapping, a number of different lithostratigraphic designations had been applied to the Cenozoic rock strata. The new map reclassifies these rocks using a new regional tectonostratigraphy (Fridrich and Thompson, 2011). Several new ${ }^{40} \mathrm{Ar} /{ }^{39} \mathrm{Ar}$ dates were produced in this study that constrain the new tectonostratigraphy and provide quantitative tests of field correlations (map sheet, figs. 1 and 2; table 1). These new correlations differ significantly from many of the previous stratigraphic correlations of Cenozoic rocks exposed in and adjacent to the Funeral Mountains.

A consistent level of geologic detail is shown on the new map, whereas in previous maps it varies greatly. In most cases, we added geologic detail; however, some previously published map data are omitted. For example, the two 1:24,000-scale geologic maps by McAllister (1970, 1973; index map, map sheet) of the Furnace Creek basin show extreme detail of outcrop geometry that we generalized for the new map. Additionally, McAllister (1971) mapped upper and lower members of the Silurian and Devonian Hidden Valley Dolomite (DSh) in part of the study area. We mapped this formation as a single unit because we were unable to consistently extend this distinction throughout the map area.

We measured numerous bedding attitudes during our fieldwork, but the majority of those on the new map are compiled from previous maps (McAllister, 1970, 1971, 1973; Cemen, 1983; Wright and Troxel, 1993). All but one of the previous maps were published at larger scales than the new map; hence, we were selective when compiling bedding attitudes. The interested reader is referred to those previous maps for the full data set.

Table 1. List of key ${ }^{40} \mathrm{Ar} /{ }^{39} \mathrm{Ar}$ ages of Tertiary units in the southern Funeral Mountains. [\#, map location symbol A-N for samples shown on simplified geologic map (map sheet, fig. 2) and geologic map; $\mathrm{Ma}$, millions of years ago; $\approx$, approximately]

\begin{tabular}{lccccl}
\hline$\#$ & Sample & Latitude (N) & Longitude (W) & Age (Ma) & \multicolumn{1}{c}{ Analyst } \\
\hline $\mathrm{A}$ & $11-10-00-1$ & $36^{\circ} 29^{\prime} 52.9^{\prime \prime}$ & $116^{\circ} 48^{\prime} 23.7^{\prime \prime}$ & $\approx 24.8$ & R.J. Fleck, USGS, this study \\
$\mathrm{B}$ & $11-14-00-1$ & $36^{\circ} 28^{\prime} 40.0^{\prime \prime}$ & $116^{\circ} 47^{\prime} 45.7^{\prime \prime}$ & 22.8 & R.J. Fleck, USGS, this study \\
$\mathrm{C}$ & Multiple & $36^{\circ} 25^{\prime} 29.8^{\prime \prime}$ & $116^{\circ} 48^{\prime} 25.2^{\prime \prime}$ & 3.1 to 3.5 & $\begin{array}{l}\text { Machette and others, 2001; } \\
\text { Knott and others, 2008 }\end{array}$ \\
$\mathrm{D}$ & $1-18-01-2$ & $36^{\circ} 25^{\prime} 39.5^{\prime \prime}$ & $116^{\circ} 43^{\prime} 12.0^{\prime \prime}$ & 8.45 & R.J. Fleck, USGS, this study \\
$\mathrm{E}$ & $3-5-02-1$ & $36^{\circ} 27^{\prime} 32.9^{\prime \prime}$ & $116^{\circ} 42^{\prime} 12.0^{\prime \prime}$ & 8.87 & D.P. Miggins, USGS, this study \\
$\mathrm{F}$ & $3-26-00-2$ & $36^{\circ} 27^{\prime} 21.7^{\prime \prime}$ & $116^{\circ} 40^{\prime}-30.4^{\prime \prime}$ & $\approx 9$ & D.P. Miggins, USGS, this study \\
$\mathrm{G}$ & $11-18-99-8$ & $36^{\circ} 24^{\prime} 31.1^{\prime \prime}$ & $116^{\circ} 41^{\prime} 07.5^{\prime \prime}$ & 8.93 & D.P. Miggins, USGS, this study \\
$\mathrm{H}$ & $3-19-03-2$ & $36^{\circ} 22^{\prime} 39.8^{\prime \prime}$ & $116^{\circ} 40^{\prime} 30.2^{\prime \prime}$ & $\approx 4.5$ & D.P. Miggins, USGS, this study \\
$\mathrm{I}$ & $3-23-00-3$ & $36^{\circ} 20^{\prime} 23.2^{\prime \prime}$ & $116^{\circ} 40^{\prime} 55.5^{\prime \prime}$ & 13.2 & D.P. Miggins, USGS, this study \\
$\mathrm{J}$ & $4-18-02-1$ & $36^{\circ} 31^{\prime} 44.9^{\prime \prime}$ & $116^{\circ} 34^{\prime} 04.0^{\prime \prime}$ & 22.58 & D.P. Miggins, USGS, this study \\
$\mathrm{K}$ & $3-1-02-1$ & $36^{\circ} 28^{\prime} 48.6^{\prime \prime}$ & $116^{\circ} 30^{\prime} 47.3^{\prime \prime}$ & 22.52 & D.P. Miggins, USGS, this study \\
$\mathrm{L}$ & $11-20-99-1$ & $36^{\circ} 24^{\prime} 09.3^{\prime \prime}$ & $116^{\circ} 30^{\prime} 45.4^{\prime \prime}$ & $\approx 22$ & D.P. Miggins, USGS, this study \\
M & $10-21-98-1$ & $36^{\circ} 22^{\prime} 49.6^{\prime \prime}$ & $116^{\circ} 28^{\prime} 55.2^{\prime \prime}$ & 22.57 & D.P. Miggins, USGS, this study \\
$\mathrm{N}$ & $10-22-98-1$ & $36^{\circ} 21^{\prime} 22.7^{\prime \prime}$ & $116^{\circ} 28^{\prime} 13.9^{\prime \prime}$ & 13.52 & D.P. Miggins, USGS, this study \\
\hline
\end{tabular}




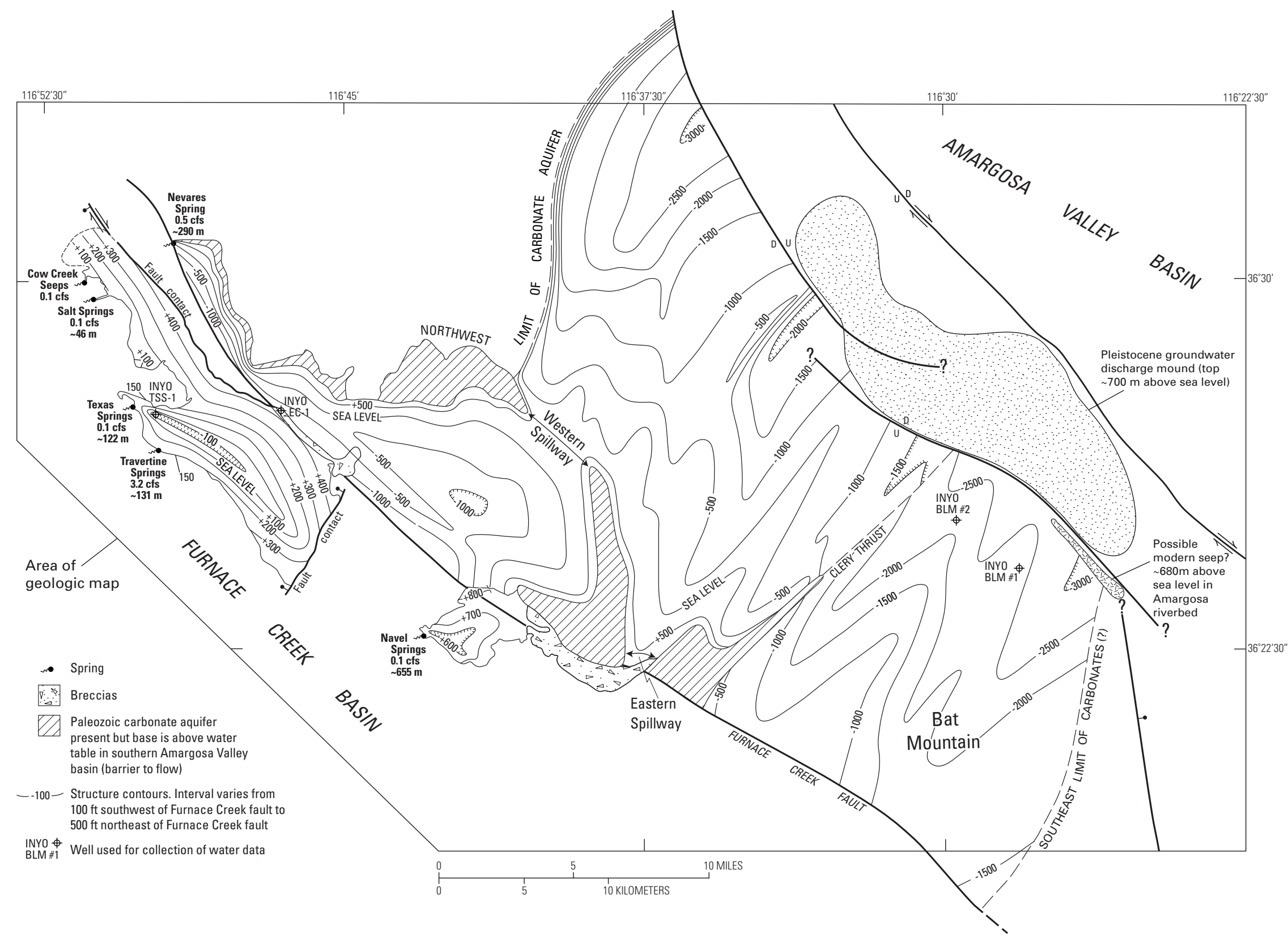

Figure 3. Hydrogeologic map showing the major springs of the Furnace Creek wash area, a modern seep, and adjacent Pleistocene groundwater discharge mound in the northeast part of map. The structure contours shown are drawn on the base of the Paleozoic carbonate aquifer within the Funeral Mountains block, and on the base of the Funeral Formation alluvial aquifer within the Furnace Creek basin. Spring elevations are in meters above sea level. Discharge is measured in cubic feet per second (cfs). 
With only one exception, the formations of the Neoproterozoic through upper Paleozoic miogeoclinal stratigraphic sequence are subdivided on the new map following widely used, modern classification schemes, such as that of Monsen and others (1992). The exception involves the Neoproterozoic Stirling Quartzite, which is divided here into five informal members using the scheme of McAllister (1971) and Wright and Troxel (1993). This scheme differs slightly from that used by most other workers in the region (for example, Stewart, 1970; Monsen and others, 1992; Niemi, 2002).

The new map covers a much larger area of surficial deposits than the previous maps, which focus on bedrock geology. Moreover, we refine mapping of the surficial deposits to show more detail and to conform to current Quaternary stratigraphic classification schemes. The surficial geologic units mapped north of latitude $36^{\circ} 30^{\prime} \mathrm{N}$ (Slate and Berry, 1999) were modified to resolve minor edge-matching conflicts with new surficial deposit mapping to the south in the Death Valley Junction 30' x 60' quadrangle (Slate and others, 2009).

\section{Geologic Summary and Interpretation of Cenozoic Tectonics}

The southern Funeral Mountains are in the Death Valley region of the Basin and Range Province. Four major packages of rocks are present in and adjacent to this mountain range. The older two of these packages are not exposed in the map area, but are exposed about 10 to $15 \mathrm{~km}$ to the northwest, in the northern Funeral Mountains (Wright and Troxel, 1993). The oldest package consists of upper amphibolite-grade metamorphic rocks, dated at about $1.7 \mathrm{Ga}$. These Paleoproterozoic rocks are considered to be the "crystalline basement" of the region.

The crystalline basement rocks are unconformably overlain by the Neoproterozoic and mainly Mesoproterozoic Pahrump Group, which was deposited as the fill of rift basins that formed premonitory to the opening of the Pacific Ocean (Link and others, 1993). The Pahrump Group is about 2-km thick in the northern Funeral Mountains (Wright and Troxel, 1993), but is known to vary greatly in thickness, even over short distances. The metamorphic grade of the Pahrump Group rocks varies throughout the region but, even at its maximum, is less than that of the crystalline basement rocks.

The Pahrump Group is overlain by a Paleozoic and Neoproterozoic marine sequence, commonly called the "miogeoclinal sequence" (Stewart and Poole, 1974). This sequence was deposited on the western continental slope and shelf of North America, and is approximately 9-km thick in the map area (McAllister, 1974). The lower part of this sequence is weakly metamorphosed in the map area, and that metamorphism is continuous with the downward-increasing metamorphism of the underlying Pahrump Group. The upper part of the miogeoclinal sequence does not show evidence of significant metamorphism.
The youngest package of rocks in the map area consists of middle to upper Cenozoic basin-fill strata deposited during tectonic extension. This extension is still ongoing in the central Death Valley basin (map sheet, fig. 2) and areas westward to the eastern front of the Sierra Nevada. The Cenozoic strata are all terrestrial sediments, the oldest of which are largely well-consolidated and well-cemented rocks; however, in much of the rest of this package, consolidation and cementation are moderate to weak.

Structures exposed in the southern Funeral Mountains are of two major age groups. First, the pre-Cenozoic (Paleozoic and Precambrian) rocks were thrust-faulted and folded during the latest Paleozoic and Mesozoic eras (Barnes and Poole, 1968; Snow, 1992). Two Mesozoic thrust fault systems, the Schwaub Peak and Clery thrusts, are well exposed in the range, along with associated northeast-trending folds, which are best illustrated on the geologic cross sections. The prograde metamorphism of the Pahrump Group and of the lower part of the miogeoclinal sequence developed during, and as a consequence of, latest Paleozoic and mainly Mesozoic contractional tectonism and thus varies greatly in its development between different thrust blocks in the region.

The majority of the exposed structures in the map area are middle to late Cenozoic, and these crosscut the Mesozoic contractional structures in the southern Funeral Mountains. The Cenozoic structures formed predominantly under conditions of extension or transtension and thus are mainly normal, oblique-slip, or strike-slip faults. Late Cenozoic transpressional structures, mainly northwest-trending folds, are also locally present, as described below. The modern basin-andrange topography of the map area formed in the late Cenozoic and is structural in origin. Retrograde metamorphism is locally developed along detachment faults of the Death Valley region. This metamorphism is late Cenozoic in age and associated with Basin-Range extension.

Cenozoic extension in the Death Valley area began at, or shortly before, $40 \mathrm{Ma}$ and consists of three phases of activity: (1) pre-basin-range, (2) syn-basin-range, and (3) post-basinrange (Fridrich and Thompson, 2011). The strata deposited in each of these phases constitute a distinct tectonostratigraphic sequence, as discussed below and shown in figure 4. Extensive erosion of the thrusted and folded pre-Cenozoic rocks occurred before the advent of weak pre-basin-range extension. Consequently, the pre-basin-range Cenozoic strata overlie a surface where the Mesozoic contractional structures have been partially beveled off, such that the basal Cenozoic strata overlie numerous different pre-Cenozoic formations across the map area.

The southern Funeral Mountains block underwent significant extension internally during the middle and late Cenozoic (see geologic cross sections on map sheet). This range stands up in relief relative to the surrounding basins mainly because the basins have incurred even greater extension. In a simplistic way, this range can be characterized as a transtensional horst block. The Furnace Creek fault, which forms the southwestern range-front, is an oblique-slip fault with dominantly strike- 
slip offset. The Amargosa Valley basin, to the northeast of the range, is at least partly a transtensional basin that is developed along the right-lateral, strike-slip Stateline fault system (also known as the Pahrump-Stewart Valley fault; Stewart, 1988; map sheet, figs. 1 and 2).

The structural boundary between the Funeral Mountains block and the Amargosa Valley basin is largely concealed under Quaternary cover; however, a very generalized geometry of faults forming this boundary has been inferred (map sheet, fig. 2) based on a combination of geophysical data and surface and borehole geological data (John Jansen and others, Ruekert-Mielke, Inc., and Fridrich, unpub. data-included in several annual administrative reports to Inyo County, 2003 to 2008). The most straightforward element of this boundary is the northwest-striking Stateline fault. Well-preserved Quaternary scarps of this fault are exposed between 2 and $4 \mathrm{~km}$ east of the map area (Fridrich, unpub. map data). These are aligned with a poorly preserved scarp at the eastern boundary of the map and with strong lineaments in Quaternary deposits about $10 \mathrm{~km}$ northwest of the scarp. Between the scarp and the lineament, the Stateline fault passes between two closely spaced outcrops of Titus Canyon Formation (Ttc) that differ strongly in lithology and stratal attitudes (map sheet). Linear anomalies in magnetic and gravity data (Blakely and others, 1999; John Jansen and others, Ruekert-Mielke, Inc., unpub. data, 2003 to 2008) coincide with these features and the gravity data allow a speculative projection of the fault about $10 \mathrm{~km}$ farther northwest. Whereas the Stateline fault is mainly a right-lateral, strike-slip fault, the gravity data indicate it has down-to-thenortheast offset across the map area.

Based on a combination of gravity and surface geologic data, two other faults are inferred along the northeastern boundary of the Funeral Mountains block. Steep gravity gradients roughly coincide with the Amargosa River, and Pleistocene alluvial deposits are domed in three areas along the south side of the river (map sheet, fig. 2), suggesting these gradients reflect recently active structures that are concealed under the riverbed. West of longitude $116^{\circ} 30^{\prime} \mathrm{W}$, the gravity data indicate down-to-the-southwest offset, bounding a northwest-trending gravity high between the river and the Stateline fault. Two small outcrops of Titus Canyon Formation (Ttc) and one of Paleozoic rocks (Eureka Quartzite; Oe) are present along the top of this gravity high on, or just north of, the State line (map sheet). The presence of these outcrops along the top of the gravity high are consistent with the interpretation that the high reflects a largely concealed horst-like uplift (see cross section $\boldsymbol{C}-\boldsymbol{C}^{\prime}$ ). East of $116^{\circ} 30^{\prime} \mathrm{W}$, the gravity data show a down-to-the-northeast gradient that is interpreted as a normal fault. Nearly all of the northwest-striking faults of the Death Valley region have a component of right-lateral, strike-slip offset, and the faults concealed under the bed of the Amargosa River are probably no exception.

Pleistocene groundwater discharge deposits, mainly calcareous paludal siltstones, occupy most of the zone between the Stateline fault and the faults inferred under the riverbed (map sheet, fig. 2), indicating that these three faults act as a partial barrier to groundwater flow. The major part of these deposits appears to comprise a constructional domical landform - a groundwater discharge mound (map sheet, fig. 2); however, structural doming may also be involved.

Two areas of tectonic denudation, resulting from synbasin-range detachment faulting, lie within the map area. First, the southeastern part of the Funeral Mountains metamorphic core complex (Hamilton, 1988) covers a large area in the northwestern part of the map (map sheet, fig. 2) and extends more than $20 \mathrm{~km}$ farther northwest. The total length of the core complex is about $35 \mathrm{~km}$ in the direction of extension (of upper-plate transport), which is about $\mathrm{N} 60^{\circ} \mathrm{W}$. Metamorphic grades in the core complex increase progressively to the west-northwest (Labotka, 1980). The gently dipping Funeral Mountains detachment fault borders the complex on all but the southeast side. Additionally, numerous small remnants of fault rocks are widespread as klippen over the top of the complex, defining a continuous, very low-angle, mullion-like fault geometry.

Originally, the Funeral Mountains detachment fault dipped to the northwest at a low to moderate angle (Hoisch and Simpson, 1993). As the upper plate was pulled off, the lower plate core complex rebounded isostatically with progressively greater uplift to the northwest. Thus the core complex was tilted to the east-southeast during its exhumation, as is reflected in the west-northwest-increasing metamorphic grade. The southeastern termination of the core complex corresponds to the zone along which the Funeral Mountains detachment fault originally daylighted, which roughly corresponds with the location of the Schwaub Peak thrust.

In the map area, the Funeral Mountains detachment fault forms the southwestern border of the core complex in a wide, anastomosing fault zone marked by numerous large fault slivers of rocks that are otherwise omitted by this fault. These faulted-out rocks are mostly mapped as blocks of the individual rock formations (map sheet) to show the internal character of the fault zone; however, all of these fault slivers are lumped as fault breccia (Tnix) on the tectonic map (map sheet,

fig. 2) and cross sections (map sheet). The detachment fault is somewhat steeper in this northwest-trending zone of exposure than it is to the northeast because this zone is a lateral ramp, of sorts, where the detachment fault dives southwestward under a large body of strongly faulted, upper-plate rocks.

Southwest of this ramp, the detachment fault extends farther to the southeast, where it is then exposed wrapping around the perimeter of an embayment named Red Amphitheatre (map sheet, fig. 2). A fragment of the Schwaub Peak thrust in the upper plate of the detachment, exposed at $36^{\circ} 27^{\prime} 35^{\prime \prime} \mathrm{N}, 116^{\circ} 44^{\prime} 45^{\prime \prime} \mathrm{W}$, has been transported about 4 $\mathrm{km}$ westward of the lower-plate projection of this fault. This fragment of the thrust fault is apparently rotated clockwise about $45^{\circ}$, reflecting oroflexural bending in proximity to the Furnace Creek fault. In support of this idea, observed straie on and near upper-plate faults in this area indicate a moderate to strong component of oblique slip. Thus the Funeral Mountains 
Geologic map of the southern Funeral Mountains including nearby Groundwater Discharges Sites

detachment fault accommodated transtensional strain, not just pure extension.

The second area of tectonic denudation is located in the Furnace Creek basin, which covers most of the southwestern part of the map, southwest of the Furnace Creek fault (map sheet, figs. 1 and 2). The Furnace Creek basin is nested within a much larger and older supradetachment basin (the Artist Drive basin) that extends far beyond the map area, to the south and southeast, and formed on the tectonically denuded lower plate of the Amargosa detachment fault. About $3 \mathrm{~km}$ southwest of the map area, along the western front of the Black Mountains, Cenozoic basin-fill sediments are exposed overlying crystalline basement rocks that are part of the lower-plate metamorphic core complex.

This relationship is important because it indicates that all of the miogeoclinal sequence and the Pahrump Group are absent from the western part of the Artist Drive basin, except as widely scattered, isolated remnants. One of these remnants is exposed under the Tertiary section at the Billie Mine (near point I on fig. 2, map sheet; not shown on map because it is too small to plot at that scale). Otherwise, the Paleozoic and upper Precambrian strata are interpreted to be absent in the map area, southwest of the Furnace Creek fault.

In the northwesternmost corner of the map area, the inactive (since about $2 \mathrm{Ma}$ ) Furnace Creek fault merges into the active northern Death Valley fault (Machette and others, 2001). Despite the name change, the two fault segments are one fault system, which has been estimated to have $\sim 80 \mathrm{~km}$ of right-lateral offset a short distance to the northwest of the map area (Stewart, 1983).

It is not completely clear when the major strike-slip faults in the central part of the Death Valley region formed. There is plausible evidence that the Furnace Creek fault may have formed during deposition of the pre-basin-range Titus Canyon Formation (Ttc; Titus Canyon assemblage; Cemen and others, 1999). Even if this is correct, the major offset on the major strike-slip faults such as this one did not occur until later, during basin-range extension.

The earliest phase of Cenozoic extension is called "prebasin-range," because it formed broad, shallow basins that trapped sediments, but did not form basin-range topography (Fridrich and Thompson, 2011). Basin-range extension in the central part of the Death Valley region began at about 14.5 Ma (Wright and others, 1991), and all of the detachment faulting in this region occurred during basin-range extension. The Funeral Mountains detachment fault was active from about 12 to $7 \mathrm{Ma}$, based on a combination of field evidence and tephrochronology (Fridrich, unpub. data) and on thermochronologic (uplift) ages (Hoisch and Simpson, 1993). The termination of movement on this detachment fault marked the end of significant extension within the Funeral Mountains block.

Detachment faulting in the Artist Drive basin began earlier, at about 14.5 Ma, but it also ended at about 6.5 Ma. Nonetheless, moderately strong extension has continued, forming several nested basins with moderate- to high-angle master faults, within the boundaries of the original suprade- tachment basin. The Furnace Creek basin, in the southwestern part of the map, is one of these nested basins that formed along the northern margin of the Artist Drive basin, between $\sim 6.5$ to $\sim 3.5 \mathrm{Ma}$, as a half-graben along the right-oblique-slip Furnace Creek fault. The central Death Valley (or Badwater) basin (see western edge of map sheet, fig. 1) is another postdetachment basin that is nested inside the Artist Drive basin, near its western boundary. This is also a half-graben and has formed along the right-oblique-slip central Death Valley fault (map sheet, fig. 1).

In the interval from about 6.5 to $3.5 \mathrm{Ma}$, extension was occurring in both the northwest-southeast and northeastsouthwest directions in the Furnace Creek basin and throughout the region (Fridrich and Thompson, 2011). In some parts of the Death Valley region, including especially the Furnace Creek basin, tectonic strain in the northeast-southwest direction changed from extensional to contractional at about 3.5 Ma; however, extension in the northwest-southeast direction continued. There is some evidence that this change occurred throughout the Death Valley region (Fridrich and others, 2000) and perhaps throughout much of the Basin and Range Province (Anderson, 2001). Since about 3.5 Ma, the northwest-southeast contraction has formed the Texas Spring syncline and all of the other northwest-trending folds within the Furnace Creek basin (map sheet, fig. 2).

\section{A New Regional Cenozoic Tectono- stratigraphy}

The classification scheme used here for the Cenozoic rocks (fig. 4) was developed by Fridrich and Thompson (2011) based on fieldwork conducted throughout the Death Valley region from 1992 to 2006. The Death Valley region is a large domain that is distinct in its structural style and resulting topography relative to adjacent regions. More importantly, the history of Cenozoic tectonism and the resulting basin-fill stratigraphy has an internally consistent pattern throughout this region; whereas both are distinctly different even short distances across the boundaries into adjacent regions (Fridrich and Thompson, 2011).

The boundaries of the Death Valley region, as defined here, are similar to those of the south half of the Walker Lane belt as defined by Stewart (1988). The region extends from the southern Nevada Test Site southward to the Garlock fault and from the Spring Mountains (on the west side of Las Vegas, Nevada) westward to the eastern front of the Sierra Nevada. Stewart (1988) showed that this region has a structural grain that reflects strike-slip strain that is greater in magnitude, or different in sense, than that in the surrounding regions.

The Cenozoic rocks of the Death Valley region are divided into three time-transgressive tectonic sequences: pre-basin-range, syn-basin-range, and post-basin-range (inset, lower middle of fig. 4). These three sequences are divided into seven distinct map assemblages that are allostratigraphic units 


\section{Cenozoic Stratigraphy of Death Valley Region}

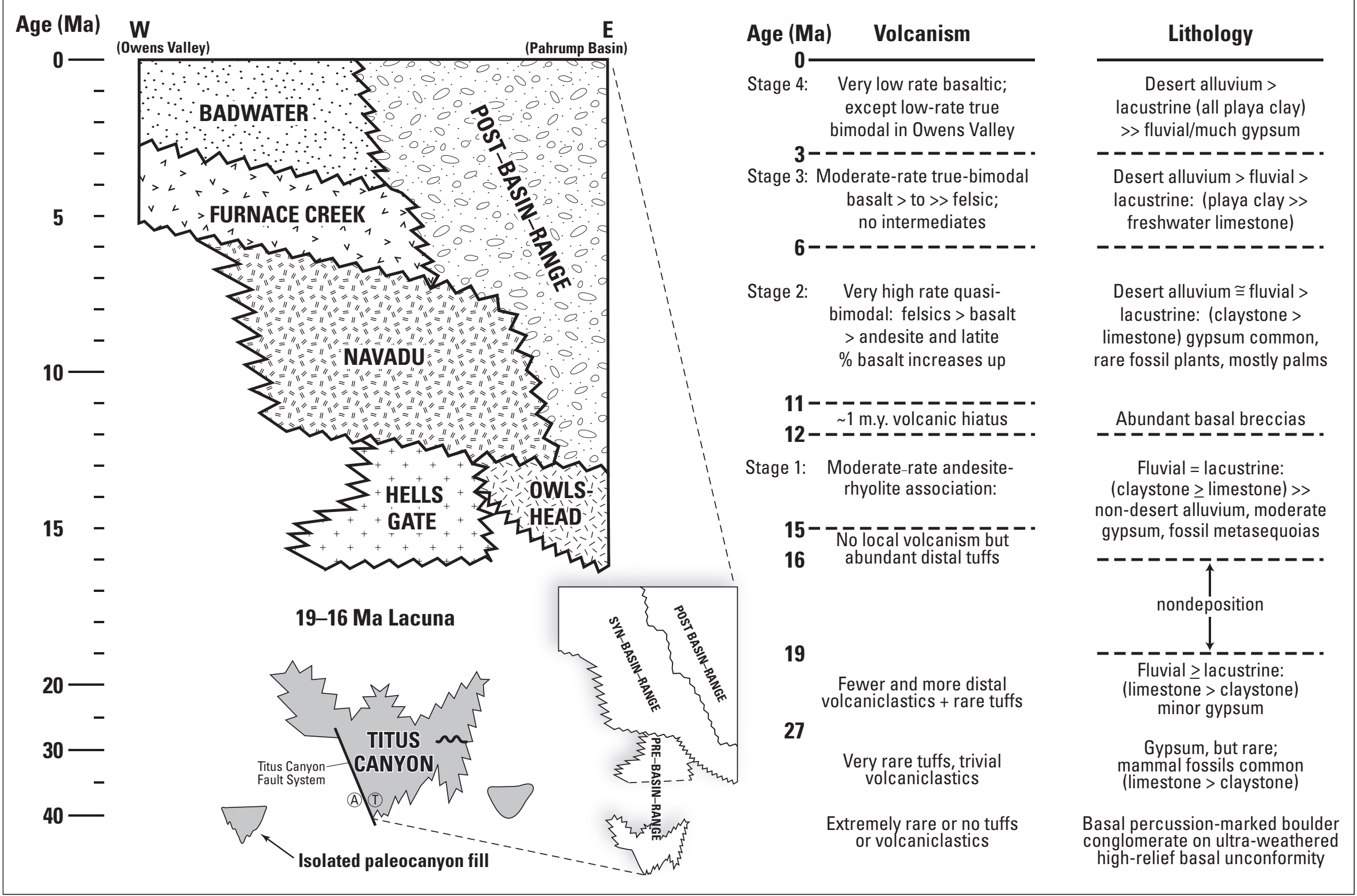

Figure 4. Four assemblages of syn-basin-range strata (Owlshead, Navadu, Furnace Creek, and Badwater) were deposited during four stages of basin-range tectonism. Each of the four tectonic stages corresponds closely with a stage of volcanic activity in the region, each of which was distinct in terms of eruptive rates and magma compositions. 
(fig. 4). They are separated by regionally extensive unconformities or disconformities (fig. 4), across which profound, abrupt changes in clast provenance and lithology (and thus depositional environment) are found. On a regional basis, and across most basins, these unconformities decrease in age to the north and west, reflecting migrating changes in tectonic patterns. Across these regionally extensive unconformities, radical changes are present in the distribution of basin-fill strata and in the pattern of facies changes within them. These changes record the creation of new basins and the major faults that bound them as well as the abandonment of older basins and their master faults.

The changes in basin and fault geometries that occurred across the regional unconformities indicate that these widespread stratigraphic boundaries record regional-scale changes in the strain regime, coincident with rapid westward migrations in the focus of tectonism. The classification system used here for the Cenozoic rocks revises and extends the tectonostratigraphy proposed by Snow and Lux (1999) for the north-central part of the Death Valley region. However, this new tectonostratigraphy is much broader in extent and is based on new fieldwork and radiometric dating throughout the Death Valley region.

\section{Pre-Basin-Range Sequence}

The pre-basin-range sequence of the Death Valley region was deposited during the initial, late Eocene to middle Miocene ( $\geq 40$ to $\approx 12 \mathrm{Ma}$ ) stage of extension (Fridrich and Thompson, 2011). The age of the base of the pre-basin-range sequence varies greatly throughout the region, partly because this sequence buried a moderately rugged paleotopographic surface. The base is as old as late Eocene northwest of the map area in the southern Grapevine Mountains, based on a titanothere skull and other mammal bones found near the base of the sequence. Stock and Bode (1935) classified these fossils as Oligocene; however, more recent correlation to well-dated fossils in Nebraska indicates they are late Eocene ( $\geq 40 \mathrm{Ma}$; oral comm., K.C. McKinney, USGS, 2002). Fluvial conglomerates are abundant in the pre-basin-range sequence, and the provenance of pebbles and larger clasts indicates derivation from western sources that are now separated from the central part of the Death Valley region by numerous ranges and closed basins - obstacles that no river could cross - and must therefore have formed later.

Bedding in the pre-basin-range strata is generally conformable with that in underlying Paleozoic and Neoproterozoic sedimentary rocks, except in the vicinity of contractional structures in which the Paleozoic and older rocks were tilted during late Paleozoic through Mesozoic compressional tectonism (Reynolds, 1969; Snow and Lux, 1999). The general conformability of the pre-basin-range strata, as well as the scarcity of fanning dips and internal unconformities within them, indicate that extension-related tilting was minimal during pre-basin-range extension. In contrast, all younger (syn-basin-range and post-basin-range) strata are strongly disconformable to the underlying Paleozoic and Neoproterozoic rocks, and fanning dips and internal unconformities are abundant in the syn-basin-range sequence.

A lacuna is present throughout the Death Valley region in the interval from about 19 to $16 \mathrm{Ma}$ (fig. 4). In the western part of the region, this lacuna separates two distinct assemblages of the pre-basin-range sequence-Titus Canyon and Hells Gate assemblages (fig. 4). The map area falls within the eastern part of the Death Valley region in which the Hells Gate assemblage is absent, and Titus Canyon strata, where present, are unconformably overlain by Owlshead strata or younger rocks.

\section{Syn-Basin-Range Sequence}

Four assemblages of syn-basin-range strata (Owlshead, Navadu, Furnace Creek, and Badwater; fig. 4) were deposited during four stages of basin-range tectonism. Moreover, each of these four tectonic stages corresponds closely with a stage of volcanic activity in the region, each of which was distinct in terms of eruptive rates and magma compositions (see volcanism column, fig. 4). The unconformities that separate the four syn-basin-range assemblages are diachronous; from southeast to northwest across the region, they become generally younger by about 1 to 2 m.y. (see Correlation of Map Units on map sheet and fig. 4). The upper and lower bounds of the four volcanic stages also show evidence of being younger to the northwest, but less so than the tectonic stages; hence, the correspondence of the two is imperfect.

The diachronous nature of the unconformities is proven by the volcanic stratigraphy. For example, the 3.2-Ma tuff of Mesquite Springs is variably found near the base of the Badwater assemblage or near the top of the Furnace Creek assemblage, depending on whether the unconformity separating them is locally older or younger than this tuff. Similarly, the youngest major rhyolite tuffs of the Owlshead volcanic field date from $\sim 12.2 \mathrm{Ma}$ and are found near the top of the Owlshead assemblage in some areas and near the base of the Navadu assemblage elsewhere. In all other cases, the distinct volcanic strata found within each of the tectonostratigraphic assemblages are key to distinguishing them, and also provide a mechanism for quantitative discrimination by radiometric dating (table 1; map sheet, fig. 2).

Between the Furnace Creek and central Death Valley faults (in the Furnace Creek basin; map sheet, figs. 1 and 2), (1) the Owlshead assemblage is called the rocks of the Billie Mine (Tos), (2) the Navadu assemblage is called the Artist Drive Formation ( $T n)$, (3) the Furnace Creek assemblage is called the Furnace Creek Formation, and (4) the Badwater assemblage is called the Funeral Formation (QTf). The last three of these formations were defined in the original mapping of the basin by McAllister (1970). McAllister (1970) included the rocks of the Billie Mine (Tos, south-central part of geologic map) in the Artist Drive Formation and considered 
this unit to be equivalent to the sedimentary part of the lower member of the Artist Drive Formation ( $\mathrm{Tnl}$ ) of the Black Mountains. However, new age constraints show that the rocks of the Billie Mine predate the Artist Drive Formation and are correlative instead with the Owlshead assemblage rocks of the southeastern Funeral Mountains (Tok, Tog, and Toss). We were unable to obtain dates from the Artist Drive Formation in the Black Mountains, due to local strong hydrothermal alteration. Nonetheless, the Artist Drive Formation in this area includes interbedded volcanic units that are easily recognized, even where altered. These units are well dated elsewhere and range in age from about 11 to $7 \mathrm{Ma}$.

Clasts of the local metamorphic rocks - those exposed in the tectonically denuded lower plates of detachment faults in the Death Valley region - are notably absent from sediments of the pre-basin-range sequence, but are present even in some of the oldest syn-basin-range deposits. The timing of appearance of these clasts in the sedimentary record closely matches the radiometrically determined uplift ages for the local metamorphic core complexes from which they were derived (Holm and others, 1992; Hoisch and Simpson, 1993; Applegate and Hodges, 1995; Hoisch and others, 1997). The abundance and especially the maximum grade of locally derived metamorphic clasts in the syn-basin-range strata increase rapidly upsection. This is consistent with radiometrically determined uplift rates for the local metamorphic core complexes, which indicate that these rocks were rapidly uplifted and exposed by tectonic denudation, rather than by erosion alone, which operates much more slowly.

\section{Post-Basin-Range Sequence}

The base of the post-basin-range sequence is defined as the horizon at which significant faulting and related tilting is buried upsection throughout the vast majority of a basin. The base of this sequence is estimated to be about 6 to $7 \mathrm{Ma}$ in the Amargosa Valley and Opera House basins and about $2 \mathrm{Ma}$ in the Furnace Creek basin (map sheet, fig. 1). The post-basinrange sequence is absent, by definition, in the central Death Valley basin because this basin is still actively subsiding. Hence, latest Pliocene to Holocene sediment in this basin is part of the syn-basin-range Badwater assemblage.

The post-basin-range sequence of the Death Valley region is not strictly post-tectonic. In many areas where basin-range tectonism has ceased, feeble late-stage tectonism has continued, with only very localized tilting of strata. Post-basin-range tectonism largely consists of horizontal offsets on a small number of large-scale strike-slip faults and block faulting along very widely spaced high-angle normal faults. For both, the tectonic rates indicated are very low compared to those of earlier syn-basin-range tectonism in the same basins. Postbasin-range strata are typically thin, even in basins in which the base is relatively old, indicating that deposition rates decline to low levels once basin-range tectonism ends.

\section{Hydrogeology}

The Paleozoic carbonate rocks exposed in the southern Funeral Mountains (map sheet, fig. 2) lie along part of the southwest termination of a vast Paleozoic carbonate aquifer system that covers most of southeastern Nevada, along with adjacent parts of southwestern Utah and southeastern California (Hunt and Robinson, 1960; Winograd, 1962; Winograd and Thordarson, 1975; Steinkampf and Werrell, 2001; Bredehoeft and others, 2005, 2008). This regional aquifer ends at the Furnace Creek fault in the southwest part of the map area, because the carbonate rocks have been tectonically removed from the vast majority of the Artist Drive basin on the southwestern side of this fault.

Throughout the Black Mountains (south of the map area), the basin-fill rocks lie on an impermeable basin floor that is a metamorphic core complex composed of crystalline basement rocks and Tertiary granitoid plutons, as discussed in the previous section. In the vast majority of the Artist Drive basin, the Paleozoic carbonate rocks are largely absent; where present, they are so extended that exposures consist only of widely scattered, isolated brecciated blocks. It is only in a narrow strip along the southeastern margin of the Artist Drive basin ( $\geq 10 \mathrm{~km}$ southeast of the map area, near Shoshone, California) where upper-plate blocks of these rocks have sufficient continuity to act as an aquifer and are hydrologically connected to the regional Paleozoic carbonate aquifer.

The Paleozoic carbonate aquifer extends from the Cambrian Bonanza King Formation ( $€ b)$ up through the Mississippian Perdido Formation (Mp; see Correlation of Map Units on map sheet) and makes up the upper $4 \mathrm{~km}$ of the 9-km-thick Paleozoic and Neoproterozoic miogeoclinal sequence previously discussed. The lower $5 \mathrm{~km}$ of this sequence consists mainly of clastic rocks - quartzites and argillites - that act as a confining unit. This confining unit thus extends from the Johnnie Formation (Zju, Zjm, and Zjl) up through the Carrara Formation ( $€ c$; see Correlation of Map Units on map sheet) and was originally named the "lower clastic aquitard" (Winograd and Thordarson, 1975). Thus, the top of the Carrara Formation is the effective base of the hydrologic system in the Funeral Mountains. About $50 \mathrm{~km}$ to the north of the map area, in and around the Nevada Test Site, the Paleozoic carbonate aquifer has an upper and a lower part, separated by the "upper clastic aquitard" (Winograd and Thordarson, 1975). This upper confining unit is absent in the map area because the local age-equivalent rocks are mainly carbonates; hence, the Paleozoic carbonates are a single, uninterrupted hydrologic unit in the map area.

The Funeral Formation (QTf) aquifer locally extends the regional aquifer system southwestward, beyond the termination of the Paleozoic carbonates at the Furnace Creek fault, and thus into the Furnace Creek basin (fig. 3). The interconnection of these two aquifers is proven by the fact that the one spring in the Furnace Creek basin that discharges directly from the Paleozoic carbonates, Nevares Spring, has water chemistry that is virtually identical to that of all but one of the other Fur- 
nace Creek springs, which discharge from the Funeral Formation at topographic low points along the southwestward termination of this formation (map sheet, fig. 2; fig. 3). Two of the Furnace Creek springs, Salt Spring and the Cow Creek Seeps (map sheet, fig. 2; fig. 3), actually appear to discharge from surficial deposits that locally extend the hydrologic system for very short distances beyond the southwestward termination of the Funeral Formation.

The Funeral Formation overlies older Tertiary units, mainly the Furnace Creek and Artist Drive Formations. Throughout the Furnace Creek basin, these formations contain abundant evaporite-bearing interbeds, they are overwhelmingly impermeable in the map area, and the few samples of groundwater recovered from them are brackish (R. Laczniak, USGS, Las Vegas, oral comm., 2006). Thus, based on existing evidence, these formations are not involved in the hydrologic system that feeds the Furnace Creek springs.

The Furnace Creek springs are interpreted as being fed mainly from the regional carbonate aquifer by interbasin flow under the southern Funeral Mountains (Hunt and Robinson, 1960; Winograd, 1962; Winograd and Thordarson, 1975; Steinkampf and Werrell, 2001; Bredehoeft and others, 2005, 2008), based principally on two lines of evidence. First, the flow from these springs is about 10 times the estimated recharge within the drainage basin of Furnace Creek. Second, the chemistry of these springs is similar to that of springs fed by the regional carbonate aquifer on the opposite side of the Funeral Mountains, in the Ash Meadows area (map sheet, fig. 1). The small difference in hydrochemistry of the Furnace Creek springs, relative to those at Ash Meadows, has been shown to be consistent with the interpretation that about 10 percent of the spring discharge at Furnace Creek is derived from local recharge (Bredehoeft and others, 2005, 2008), mainly from rainfall on the Funeral Mountains.

The base of the carbonate aquifer is strongly uplifted under the Funeral Mountains, relative to the Amargosa Valley basin to the north, restricting flow from north to south across the range. Nonetheless, in two areas under the range, pathways exist where the base of the carbonates extends below the elevation of the water table in the adjacent part of the Amargosa Valley basin (fig. 3). On the hydrogeologic map (fig. 3), these two areas are labeled as "spillways" because they are interpreted to have a dual effect. First, the spillways are conduits for interbasin flow. Second, because of their height and limited cross-sectional area, the spillways are responsible for holding up the water table under the Amargosa Valley basin, which is much higher than that in the Furnace Creek and central Death Valley basins.

The eastern of the two spillways is very narrow, but it may contribute to the flow from Navel Spring. Large travertine deposits, of middle Pliocene to early Pleistocene age, are present in the Furnace Creek basin immediately to the south and southwest of the eastern spillway, suggesting that this feature hosted strong groundwater flow in earlier, wetter periods. All of the other springs in the Furnace Creek wash area are fed by interbasin flow through the western spillway. Navel
Spring is higher in elevation than the rest of the Furnace Creek springs (map sheet, fig. 2) and has distinct water chemistry. All of the other major springs in the Furnace Creek basin are nearly identical in their hydrochemistry and temperature (Steinkampf and Werrell, 2001).

All of the major springs are a uniform $97^{\circ} \mathrm{F}\left(36^{\circ} \mathrm{C}\right)$, $\approx 20$ Fahrenheit degrees ( $\approx 11$ Celsius degrees) above the mean annual air temperature. The carbonate aquifer extends to depths of greater than 1 kilometer at a distance of roughly $20 \mathrm{~km}$ up the flow path from the springs (to the east-northeast; see geologic cross sections on map sheet and fig. 3 ) and is confined under a thick fill of Cenozoic strata to the north of the Funeral Mountains block in the Amargosa Valley basin. Consequently, upwelling of warm water from depth is an expected observation from the interbasin flow model (Bredehoeft and others, 2008, and references therein). Further, the configuration of the carbonate aquifer under the southern Funeral Mountains results in channelized flow through the spillways. Excepting tiny Navel Springs, all of the springs of the Furnace Creek basin are fed through the western spillway; flow to these springs is thus confined to a single narrow pathway, as reflected in the nearly uniform temperature and chemistry of the spring water.

On the hydrogeologic map (fig. 3), there are two additional features that bear discussion. The first is an apparent modern seep, present in the bed of the Amargosa River, about 4 to $7 \mathrm{~km}$ west of the eastern map border, which is marked by a dense mesquite bosque. It is unknown whether this seep reflects upwelling of groundwater from the Paleozoic carbonate aquifer along the faults inferred under the riverbed, or subsurface flow, through channel sands, that is locally forced to the surface. There is also some question as to whether this seep is perennial.

A second notable feature is the breccia that largely, if not entirely, intervenes between the Paleozoic carbonate aquifer and the Funeral Formation aquifer, in the Furnace Creek fault zone (fig. 3). Computer modeling (Bredehoeft and others, 2005,2008 ) shows that the breccia must impede flow, relative to the aquifers on either side, or the water table would not be high enough on the upthrown side of the Furnace Creek fault for Nevares Spring to flow.

In order to test this modeling result, a hydrologic exploration well, the Inyo-EC-1, was drilled at the mouth of Echo Canyon (see cross section $\boldsymbol{B}-\boldsymbol{B}^{\prime}$ on map sheet). In this well, about $360 \mathrm{~m}$ of fault-zone breccia (of mainly rock-fall origin) was rotary-drilled and cored before pre-basin-range strata (Titus Canyon Formation-Ttc) was penetrated below. The parent rock for the breccia is evidently the Nopah Formation $(€ n)$, which is about half limestone and half dolomite with minor insolubles - mainly clay, silt, and sand. In contrast, the breccia in the well was found to consist of clumps of shattered dolomite (no limestone) enclosed in a matrix of insolubles, in significantly greater abundance than in the parent rock. This matrix commonly has the form of a network of stylolitic clay seams throughout the rock. Well Inyo-EC-1 was drilled to a 
depth of about 300 meters before groundwater first entered the hole, which then slowly rose to a depth of 88 meters below land surface, demonstrating poor hydraulic conductivity.

A huge volume of water must have passed through the fault-zone breccias to dissolve away the limestone, ultimately resulting in great loss of permeability. Such large-scale limestone dissolution is consistent with: (1) millions of years of interbasin flow through the southern Funeral Mountains; and (2) the large volume of travertine that is found in the Furnace Creek basin, especially in the about 5 to $3 \mathrm{Ma}$, capping travertine unit (Tft) of the Furnace Creek Formation. 


\title{
DESCRIPTION OF MAP UNITS
}

\author{
SURFICIAL DEPOSITS
}

af

QTac

Qayy

Qayo

Qay

Qp

Qc

Qm

QIs

Qai

Qao

QTa

Artificial fill (late Holocene)

Surficial deposits, undivided (Holocene to upper Miocene) — Combined unit, used only on geologic cross sections

Alluvial deposits in annually active channels (late Holocene) — Sand, silt, and lesser gravel, intermixed and interbedded; unconsolidated, poorly to moderately well sorted, poorly to well bedded, locally crossbedded; mapped only in the bed of the Amargosa River, which is far more active than any other drainage in the area

Alluvial deposits in recent low terraces (middle and early Holocene) — Gravel, sand, and silt; intermixed and interbedded; unconsolidated to weakly consolidated, poorly to moderately well sorted, poorly to well bedded, locally crossbedded. Clasts are angular to subrounded; locally well rounded. Surface has faint bar-and-swale morphology with cobbles marking former bars that are slightly higher than pebbly swales, or is planar with slightly to locally moderately packed pavement. Pavement clasts are weakly to moderately varnished. Soil typically has cambic B horizon and stage I carbonate horizon. Thickness of unit generally ranges from less than $1 \mathrm{~m}$ to $10 \mathrm{~m}$, but may be as thick as $20 \mathrm{~m}$ adjacent to tectonically active mountain fronts

Alluvial deposits in recently active channels (Holocene) - Gravel, sand, and silt; intermixed and interbedded; unconsolidated, poorly to moderately well sorted, poorly to well bedded, locally crossbedded. Clasts are commonly angular to subrounded; locally well rounded

Playa sediments (Holocene)—Silt, fine sand, clay, and evaporites; intermixed and interbedded; polygonal desiccation cracks common; exposed on floor of Death Valley

Colluvial deposits (Holocene and Pleistocene) - Angular to subangular, granule- to boulder-size clasts with variable amounts of sand, silt, and clay as matrix. Generally unsorted and nonbedded or poorly bedded; matrix partly of eolian origin, locally cemented by carbonate. Forms talus deposits and thin mantles of debris along flanks and bases of steep slopes; deposited by rainwash, sheetwash, creep, and mass wasting

Marl (Holocene and Pleistocene) - Calcareous siltstone, pale-yellowish-brown, yellowish-gray or grayishorange; weathers white to very light gray; silty to sandy; soft, plastic when wet. Consists of calcite, various clay minerals, quartz and opaline silica, silt, and sand-size rock fragments. Includes several thin chalk beds as thick as $1 \mathrm{~m}$ and discontinuous beds of small, irregular limestone nodules. Locally contains sparse to common pencil-size calcified plant stems. Unit is thought to represent deposits and precipitates formed in areas of groundwater discharge, including paludal environments. Reported ages in the Amargosa Valley basin are Pleistocene (90 ka to $15 \mathrm{ka}$; Paces and others, 1997); deposits at Nevares Spring are probably Holocene. Deposits too small to map are present at all of the other springs in the Furnace Creek basin

Landslide deposits (Holocene and Pleistocene) — Breccia formed in recent landsliding; landslide geomorphology is pristine to weakly dissected

Alluvial deposits in mid-level terraces (late Pleistocene) - Gravel, sand, and silt; intermixed and interbedded, weakly to moderately well consolidated. Clasts are unsorted to moderately well sorted, poorly to well bedded, angular to rounded. Surface is planar with moderately packed to densely packed pavement; pavement clasts are moderately to well varnished. In places, thin eolian sand deposits mantle the surface. Soil development varies from a cambic B horizon and a stage I to II carbonate horizon to an argillic B horizon and an approximately 1-m-thick stage III to IV carbonate horizon. Thickness of unit less than 1 $\mathrm{m}$ to $10 \mathrm{~m}$

Alluvial deposits in high terraces (Pleistocene) — Gravel, sand, and silt; intermixed and interbedded, light gray, moderately well consolidated. Clasts are unsorted to moderately well sorted, nonbedded to well bedded, angular to rounded; matrix is sandy to silty. Surface is planar with densely packed pavement; pavement clasts are well varnished making this unit medium to dark colored on most surfaces. In places, thin eolian sand deposits mantle surface. Soil development varies from a well-developed cambic B horizon and a stage II carbonate horizon to an argillic B horizon and an approximately 1-m-thick, stage III to IV carbonate horizon. Thickness of unit less than $1 \mathrm{~m}$ to $10 \mathrm{~m}$

Old alluvial deposits (early Pleistocene and late Pliocene) - Gravel, sand, and silt; intermixed and interbedded; light brownish gray to light gray. Clasts are angular to subrounded, generally poorly sorted, poorly bedded, and moderately to well cemented with carbonate. Surface is eroded and dissected; commonly 
forms rounded ridges or ballenas. Where preserved, pavement is generally moderately to densely packed and includes tabular fragments cemented by pedogenic carbonate and opaline silica; varnish on pavement clasts is variable but commonly strongly developed. Soils typically consist of a stage III to IV carbonate horizon as much as $2 \mathrm{~m}$ thick; argillic horizons, where present, postdate much of the erosion. Thickness of unit may exceed $40 \mathrm{~m}$

Landslide deposits (early Pleistocene and late Pliocene) - Rock-avalanche breccias exposed as tongues extending from Bat Mountain (at southeastern limit of Funeral Mountains; map sheet) onto alluvial apron to east; composed of clasts derived primarily from Kelleys Well Limestone (Tok) and red sandstone member (Ttr) of Titus Canyon assemblage; also includes erosionally dissected landslide masses exposed in Furnace Creek valley; maximum exposed thickness is about $15 \mathrm{~m}$

\section{SYN-BASIN-RANGE SEOUENCE}

Consists of Badwater, Furnace Creek, Navadu, and Owlshead assemblages (fig. 4)

Badwater assemblage (lower Pleistocene to Pliocene) - Consists of the Funeral Formation, which has a sedimentary facies (QTf) as well as a basalt facies (Tby), locally interbedded near the base

Sedimentary facies of Funeral Formation (lower Pleistocene to Pliocene) - Alluvial conglomerates with angular to subangular clasts as large as $1 \mathrm{~m}$; moderately to poorly consolidated; clasts derived from Paleozoic and Neoproterozoic rocks exposed in adjacent southern Funeral Mountains; strongly fanning dips present in basal 10 to $30 \mathrm{~m}$; maximum exposed thickness of about $200 \mathrm{~m}$. Maximum measured subsurface thickness of $305 \mathrm{~m}$, seen in well Inyo-TSS-1 in center of Texas Spring syncline. In this deepest part of the basin, formation has thin interbeds of playa siltstones in middle and lower parts and, in all but top $70 \mathrm{~m}$ of unit, similar siltstone forms a dense matrix around alluvial clasts, such that only uppermost, siltfree $70 \mathrm{~m}$ of formation has significant permeability. Base of formation is about $5 \mathrm{Ma}$ in south-central part of map area, decreasing to less than 3.1 Ma to northwest (fig. 2, sheet 1; and table 1; based on ${ }^{40} \mathrm{Ar}{ }^{39} \mathrm{Ar}$ dates by D. Miggins, USGS (unpub. data, 2007) and Knott and others, 2008)

Basalt facies of Funeral Formation (Pliocene) - Olivine basalt lava flows and related local scoria deposits, phenocryst-poor, locally interfingers with lowermost part of Funeral Formation (QTf) in south-central part of map; superimposed hachure pattern indicates oxidized vent areas; maximum exposed thickness of about $175 \mathrm{~m}$ near south-central map boundary; dated at $4.5 \mathrm{Ma}$ (whole-rock, ${ }^{40} \mathrm{Ar} /{ }^{39} \mathrm{Ar}$; sample $\mathrm{H}$, table 1)

Furnace Creek assemblage (upper Pliocene to upper Miocene) - Includes Furnace Creek Formation and Greenwater Volcanics

Furnace Creek Formation (upper Pliocene to upper Miocene)-Maximum exposed thickness of about $2.2 \mathrm{~km}$

Travertine (Pliocene) - Travertine, thin- to medium-bedded, with interbeds of siltstone (mainly paludal groundwater discharge deposits) and lesser pebble conglomerate; classified by McAllister (1970) as base of Funeral Formation (QTf); classified here as the top of Furnace Creek Formation owing to greater concordance with playa claystones (Tf), below, than with Funeral Formation conglomerates (QTf); perhaps best considered as transitional between the two formations. Deposited by springs and seeps at the toes of alluvial fans (of QTf) that built outward from the mountain front, and northwestward across the Furnace Creek basin, over playa deposits ( $\mathrm{Tf}$ ); thus, a diachronous regressional deposit, formed in the interval from $\approx 5$ to $\approx 3$ Ma based on stratigraphic bracketing

Upper claystone (Pliocene) - Claystone, pale yellow with pumiceous ash-fall tuffs at base, dated at 3.1 to 3.5 Ma (sanidine, ${ }^{40} \mathrm{Ar} /{ }^{39} \mathrm{Ar}$; samples $\mathrm{C}$, table 1)

Playa and playa margin rocks of Furnace Creek basin (Pliocene to upper Miocene)-Interbedded playa claystones, siltstones, and sandstones with minor thin limestone and marl interbeds; locally gypsum-bearing or pebbly; moderately to well consolidated, thin- to medium-bedded, pale yellowish tan to light ochre-brown

Upper and middle conglomerates (Pliocene) - Conglomerate beds found throughout middle and upper part of Furnace Creek Formation; composed mainly of clasts either of Artist Drive Formation lithologies from Black Mountains, or Paleozoic and Neoproterozoic sedimentary lithologies from Funeral Mountains. In both cases, supporting matrix is typically bentonitic sandstone and can be many different bold colors, such as greens, yellows, reds, and browns

Gypsum-rich member (Pliocene) — Claystone with abundant gypsum; locally contains minor borate deposits 
Rock-fall breccias (lower Pliocene to upper Miocene) - Breccias formed mainly in rock falls, composed of clasts of various Paleozoic formations exposed east of Travertine Point along southwest range-front of southern Funeral Mountains; transitional to adjacent giant-block breccias (Tflx); matrix is crushed rock of the same lithology as the enclosed clasts

Tflx

Giant-block breccias (lower Pliocene to upper Miocene) - Genetically related to rock-fall breccias (Tfrx) but composed of clasts that are large enough to map at 1:50,000 scale; rock formations from which giant blocks were derived shown in parentheses (for example, Tflx(Op)); dot-dash blue lines denote contacts between giant blocks and are labelled "giant-clast boundary within megabreccias"

Basal conglomerate (upper Miocene) - Conglomerate beds found at base of Furnace Creek Formation; contains well-rounded to subrounded pebble- to small boulder-size clasts of Paleozoic sedimentary lithologies and Hunter Mountain Quartz Monzonite from the Panamint Range (on the west side of the central Death Valley basin), mixed with clasts of Artist Drive Formation lithologies from Black Mountains, in a sandstone matrix

Greenwater Volcanics (middle Pliocene to upper Miocene) - Interfingers laterally with Furnace Creek Formation

Basalt - Sparsely vesicular lava flows and much lesser scoria, with sparse olivine and plagioclase phenocrysts; charcoal gray

Pyroclastic deposits-Felsic, nonwelded ash-fall tuffs, mainly dacitic and biotite-rich, light gray; probably correlative with petrographically similar lava flows and agglutinated ash-fall tuffs found to south and southeast of map area, including the dacite of Brown Peak

Th

Navadu assemblage, undivided (upper to middle Miocene; about 6.5 to 12 Ma)—Includes the Artist Drive Formation in the Furnace Creek basin and age-equivalent strata in the Funeral Mountains.

Combined unit used only on cross sections

Artist Drive Formation (Miocene) - Name applied by McAllister (1970) to Navadu strata exposed on southwestern margin of Furnace Creek basin, at north end of Black Mountains. Maximum exposed thickness of about $1.6 \mathrm{~km}$. Divided here into three informal members, lowermost of which is subdivided into a sedimentary part and a mafic volcanic part that partially interfinger with each other. Coeval basinfill strata (Artist Drive Formation equivalent) were deposited in half-grabens within Funeral Mountains, and within the Furnace Creek fault zone on southwest flank of these mountains

Upper member-Upper sedimentary part consists of fluvial conglomerates grading down into sandstones and then into interbedded claystones and freshwater limestone. Lower volcanic part consists of felsic tuffs of upper part of Shoshone Volcanics (Wright and others, 1991) and lesser, interbedded basalt flows at base. Equivalent to McAllister's (1970) upper sedimentary and upper pyroclastic members, combined

Middle member - Upper sedimentary part consists of sandstones grading down into interbedded lacustrine claystones and freshwater limestone. Lower volcanic part consists mainly of felsic lavas and tuffs of lower part of Shoshone Volcanics. Equivalent to middle sedimentary and lower pyroclastic members of McAllister (1970), combined

\section{Lower member} Sedimentary part—Pebbly sandstone and interbedded, locally gypsiferous claystone. Equivalent to lower sedimentary member of McAllister (1970)

Volcanic part - Basalt and andesite lavas and possible related intrusives; andesite is correlative with the 11-Ma Sheephead Andesite (Wright and others, 1991), a widespread unit exposed to south, southeast, and southwest of map area that commonly contains abundant large laths of plagioclase in radiating clumps; basalt has a moderate abundance of plagioclase and olivine phenocrysts. Equivalent to basaltic rocks of Artist Drive Formation of McAllister (1970)

Artist Drive Formation equivalent, undivided (Miocene) - Strata deposited between about 7 and $12 \mathrm{Ma}$ within and along the flanks of the Funeral Mountains. Mapped by McAllister $(1970,1971,1973)$ as Furnace Creek Formation; however, intercalated ash-fall tuffs correlate with the about 8-10 Ma Shoshone Volcanics, based on petrographic character and ${ }^{40} \mathrm{Ar} /{ }^{39} \mathrm{Ar}$ dates (see table 1, samples D, E, F, and $\mathrm{G})$; divided on map into four lithologic subunits:

Tng Alluvial - Alluvial conglomerates deposited in small basins formed on downthrown sides of major Miocene faults within southern Funeral Mountains; composed of clasts derived from various Paleozoic rock formations as well as rare clasts of Titus Canyon Formation (Ttc) typically moderately consolidated and pale yellow in color; locally includes interbedded freshwater limestones 
Rock-avalanche breccias-Megabreccias and much lesser mesobreccias composed of clasts of various Paleozoic rock formations exposed in the southern Funeral Mountains; interbedded with alluvial and playa subunits (Tng and Tnp) and giant-block landslide breccias (Tnlx); transitional to giant-block landslide breccias (Tnlx). Key beds within unit are extensive tephras that show large-scale bedding geometry of clasts that are large enough to map at 1:50,000 scale; rock formations from which giant blocks were derived are shown in parentheses (for example Tnlx (Op); dot-dash blue lines denote contacts between giant blocks and are labelled "giant-clast boundary within megabreccias," whereas internal solid black lines denote formation contacts within giant blocks. Where space was limited, geologic unit labels were assigned numbers and a table has been provided on map sheet that lists the numbers and their corresponding unit label

Thix Fault breccia (Miocene) - Brecciated Paleozoic rocks exposed within the Furnace Creek fault zone and other major fault zones; assigned to Navadu assemblage because Navadu tectonic stage was principal interval of movement on this fault; actual interval in which these breccias formed may be broader. Also used on map for fault breccia along the Funeral Mountains detachment fault, mainly composed of shattered Wood Canyon Formation $(€ Z w)$. Used more extensively on the cross sections, where numerous thin slivers of rock (mainly upper and lower Stirling Quartzite; Zseb and Zsa) caught up in the Funeral Mountains detachment fault zone are identified individually on the map, but are shown as fault breccia on the cross sections

To Owlshead assemblage, undivided (middle Miocene; about 12 to 14.5 Ma) - Composed of rocks of Billie Mine, to south of Furnace Creek fault, and Bat Mountain Formation, north of this fault, at southeast limit of Funeral Mountains. Combined unit used only on cross sections; divided on map into:

Rocks of Billie Mine (middle Miocene) - Orange sandstone, well consolidated, commonly with wellrounded pebbles mainly of quartzite, black chert, and Hunter Mountain Quartz Monzonite; fines upward: fluvial at base and at least partly lacustrine in upper part; includes thin interbedded ash-flow and ash-fall tuffs in lower part that yielded dates of 12.7 and 13.7 Ma (K-Ar, Wright and others, 1999) and 13.2 Ma $\left({ }^{40} \mathrm{Ar}{ }^{39} \mathrm{Ar}\right.$, sanidine, sample I, table 1); maximum exposed thickness of about $150 \mathrm{~m}$

Bat Mountain Formation (middle Miocene)

Sandstone member - Volcaniclastic arkosic sandstone with minor thin conglomerate and mudstone interbeds; dominantly ochre colored; commonly crossbedded indicating a braided-stream depositional environment; contains sparse pebbles derived from various Paleozoic rock formations of southern Funeral Mountains and vicinity; a waterlaid tuff exposed at top was dated at about $13.5 \mathrm{Ma}\left({ }^{40} \mathrm{Ar} /{ }^{39} \mathrm{Ar}\right.$, sanidine, sample N, table 1); maximum exposed thickness of about $300 \mathrm{~m}$

Conglomerate member - Pebble to boulder (dominantly cobble) alluvial conglomerate, mainly clast supported, with a poorly sorted matrix of dirty sandstone; clasts are typically subangular and consist of various Paleozoic lithologies derived from southern Funeral Mountains and vicinity; also contains much lesser clasts of Kelleys Well Limestone (Tok) and red sandstone member of Titus Canyon assemblage (Ttr) - only in basal $50 \mathrm{~m}$ of unit; interfingers at base with Kelleys Well Limestone and at top with sandstone member; overall color as observed from a distance is medium-reddish brown; maximum exposed thickness of about $300 \mathrm{~m}$

Kelleys Well Limestone (middle Miocene) - Massive to thick-bedded, micritic cream-white freshwater limestone with local biostromes of finely laminated algal limestone and rare lenses of interbedded conglomerate resembling overlying cobble conglomerate member of Bat Mountain Formation (Tog). Unit contains numerous small rootless slump faults that strike roughly north-south and sole into bedding downsection, and are progressively buried upsection; maximum exposed thickness of about $100 \mathrm{~m}$

\section{PRE-BASIN-RANGE SEQUENCE}

Titus Canyon assemblage (early Miocene to Oligocene) - A group of correlative rock formations that includes Titus Canyon (Wright and Troxel, 1993), Ubehebe (Snow and Lux, 1999), and Amargosa Valley Formations (Cemen and others, 1999). All three of these formation names have been used in the Funeral Mountains by these authors. Three informal members (units Ttr, Ttl, and Ttg) are taken from Cemen and others (1999). That report also designated an upper member of Amargosa Valley Formation, which is included here in the red sandstone member (Ttr), based on lithology and new ${ }^{40} \mathrm{Ar} /{ }^{39} \mathrm{Ar}$ dating conducted in this study ( 22 Ma, sample L, table 1) 
Titus Canyon Formation, undivided (early Miocene to Oligocene) - Undivided unit only used for scattered small exposures where lithologic subdivision is impractical at 1:50,000 scale, and on geologic cross sections; elsewhere subdivided into:

Red sandstone member (early Miocene) - Pebbly sandstone and much lesser interbedded thin marl and pebble to small-cobble conglomerate; medium-red to much lesser grayish-green or, rarely, ochre colored; pebbles moderately to well rounded and derived mainly from Paleozoic and Neoproterozoic lithologies of southwestern Great Basin - chiefly quartzites and black cherts, along with rare pebbles of Mesozoic granite, mainly Hunter Mountain Quartz Monzonite; sand is arkosic, typically rich in biotite flakes, and mainly volcaniclastic; tuff filling a paleochannel at top of section exposed on southern Bat Mountain was dated at about 19.5 Ma (K-Ar, biotite; Cemen, 1983; not shown on figure 2 (map sheet) because exact sampling location is unknown); maximum exposed thickness of about $300 \mathrm{~m}$

Limestone member (early Miocene to Oligocene) - Freshwater limestone and marl beds interbedded with equally or more abundant tuffaceous siltstones, sandstones, and minor tuffs; moderately well consolidated except for claystones, which are mostly poorly consolidated. Tuff near base was dated at $24.7 \mathrm{Ma}$ (K-Ar; Cemen, 1983), but was petrographically identified in this study as the 27-Ma Monotony Tuff; tuff near top is dated at $22.6 \mathrm{Ma}\left({ }^{40} \mathrm{Ar} r{ }^{39} \mathrm{Ar}\right.$, sample $\mathrm{M}$, table 1). Unit includes interbedded fluvial conglomerates in small isolated exposures about 10 to $16 \mathrm{~km}$ northwest of Bat Mountain; maximum exposed thickness of about $120 \mathrm{~m}$

Conglomerate member (Oligocene) - Alluvial conglomerate, moderately consolidated, consisting of subangular clasts to about $1 \mathrm{~m}$, derived from locally subcropping Paleozoic rock formations, in a matrix composed of lateric red clay and lesser sand that is volcaniclastic near top of unit; thickness highly variable, maximum of about $225 \mathrm{~m}$

\section{PRE-TERTIARY UNITS}

Perdido Formation (Mississippian) - Medium- to dark-gray limestone with interbedded lesser siltstone and sandstone; top eroded; maximum preserved thickness of about $155 \mathrm{~m}$

Tin Mountain Limestone (Mississippian) —Limestone, mainly dark to light gray; commonly crinoidal or cherty, with some thin minor pale red argillaceous beds; estimated maximum thickness of about $100 \mathrm{~m}$

Lost Burro Formation (Devonian) - Consists of three parts: upper $340 \mathrm{~m}$ is medium-gray, mixed dolomite and limestone overlain by light-gray limestone that is sandy at very top; middle $300 \mathrm{~m}$ is light-gray dolomite with some widely spaced dark-gray beds; basal $80 \mathrm{~m}$ is light-gray dolomite interbedded with dark-brown weathering siltstone, sandstone, and chert beds

Hidden Valley Dolomite (Devonian and Silurian) - Upper part is light-gray, slightly argillaceous dolomite; lower part is dark-gray, cherty dolomite. This color distinction is locally mapped as a key bed (see map sheet), but elsewhere may be modified by alteration and thus may not be consistent across map area. Thickness varies from $265 \mathrm{~m}$ in southeast part of map to $440 \mathrm{~m}$ in northwest part

Ely Springs Dolomite (Ordovician)—Dolomite and limy dolomite, containing abundant dark-gray chert layers and nodules 5 to $20 \mathrm{~cm}$ thick; dark gray grading to medium gray at top; maximum thickness of about $150 \mathrm{~m}$

Eureka Quartzite (Ordovician) - Ledge-forming, white to pink orthoquartzite, grading down into a light- to medium-red dolomitic sandstone at base; estimated maximum thickness of about $120 \mathrm{~m}$

Pogonip Group, undivided (Ordovician) - Undivided unit used mainly on the cross sections, but also locally on the map. Estimated maximum thickness of about $670 \mathrm{~m}$

Antelope Valley Limestone - Limestone and silty limestone; Medium-gray; finely to coarsely crystalline and predominantly nodular, massive to laminated beds

Ninemile Formation - Siltstone and shale, light- to moderate-brown or reddish-brown, and typically finely interlaminated with olive-black to dark medium-gray, silty limestone or dolomite

Goodwin Limestone - Limestone and lesser silty limestone, ledge-forming, medium- to dark-grey

Nopah Formation, undivided (Cambrian) - Combined unit used only on cross sections; consists of three members: a thin basal shale member, and two carbonate members that are locally mapped together as a combined unit; estimated maximum thickness of about $520 \mathrm{~m}$

Smoky and Halfpint Members, undivided

Smoky Member-Dolomite, cliff-forming, very light gray to medium gray, in indistinct medium to thick beds 
Enh Halfpint Member-Dolomite with locally abundant black chert nodules and layers; medium to dark gray; thin to thick bedded, finely to coarsely crystalline, bedding generally very indistinct

End Dunderberg Shale Member-Fissile shale, greenish brown with subordinate interbeds of medium gray to pale brown, thinly bedded limestone

$€ b$

$€ b b$

Ebbu

€bbl

Ebp

$\epsilon c$

$€ z$

$€ Z w$

Ewu

Zwm

Zwl

Zseb

Zse

Zsd

Zsc

Zsb

Zsa

Zju

Zjm

Zjl

Yk

Bonanza King Formation, undivided (Cambrian) - Light- to dark-gray limestone and dolomite with much lesser orange-brown silty layers; combined unit used only on cross sections; estimated maximum thickness of about $1,100 \mathrm{~m}$

Banded Mountain Member-Combined unit consisting of the following two units:

Upper part—Dolomite and limestone, cliff-forming, fine to medium crystalline, thickly bedded; composed of three color bands of approximately equal thickness, from base to top: light gray, dark gray, and medium gray

Lower part - Dolomite and limestone, distinctively striped in alternating light- to dark-gray beds ranging from 0.5 - to 6-m thick

Papoose Lake Member-Mostly dark-gray dolomite and limestone intercalated with sparse but distinctive yellowish-orange, silty and sandy intervals

Carrara Formation (Cambrian) - Heterogeneous unit of shale or slate and lesser micaceous siltstone intercalated with three prominent beds of dark greenish-gray limestone and silty limestone; estimated maximum thickness of about $490 \mathrm{~m}$

Zabriskie Quartzite (Cambrian) - Orthoquartzite, cliff-forming, dark to medium purplish red, fine to medium grained, thick bedded, commonly cross-stratified; estimated maximum thickness of about $250 \mathrm{~m}$

Wood Canyon Formation, undivided (Cambrian and Neoproterozoic) - Thick sequence of argillites (weakly metamorphosed siltstone) with interbeds of sandstone and dolomite; combined unit used only on cross sections. Estimated maximum thickness of intact formation is about 1,200 $\mathrm{m}$

Upper member (Cambrian) - Sequence of interbedded quartzite and siltstone with numerous orange dolomite beds are most abundant at and near base and are commonly oolitic

Middle member (Neoproterozoic) - Fining-upward sequence consisting mainly of siltstone, but with abundant interbedded thin sandstone beds in lower part, and a pebbly arkosic sandstone at base; sandstones are pale-greenish gray; siltstones are medium- to dark-greenish brown

Lower member (Neoproterozoic) - Siltstone and very fine-grained micaceous quartzite, thin to thick bedded, dark- to medium-brown, or greenish-gray section is divided into four sections of roughly equal thickness by three prominent, about 15 -m-thick beds of interbedded orange dolomite mapped as key beds

Stirling Quartzite (Neoproterozoic) - Estimated maximum thickness of about 1,500 m; divided on map into 5 units and on cross sections into 2 units, as described below:

Upper part, undivided - Consists of upper four members (Zse, Zsd, Zsc, and Zsb) combined; used only on cross sections

E member - Orthoquartzite, fine grained, medium to thick bedded, white to pale yellowish-brown or pale red

D member-Fine- to medium-grained feldspathic sandstone, with numerous siltstone interbeds in lower part of unit, decreasing in abundance upward

C member-Dolomite, fine to medium grained, massive to thin bedded, typically pale orange

B member-Fine-grained arkosic sandstone, micaceous siltstone, and thin beds of carbonate rocks

Lower part (A member) - Impure sandstone, mostly fine to coarse grained, commonly arkosic and bearing characteristic jasperoid grains and small pebbles; includes abundant beds of quartz-pebble conglomerate near base and a thin, orange dolomite marker bed in upper part

Johnnie Formation (Neoproterozoic) - Shale (or slate or schist) and lesser carbonate rocks; divided on cross sections into three map units; only uppermost $100 \mathrm{~m}$ of upper member exposed in map area; thus, middle and lower members, and the underlying Kingston Peak Formation are projected onto cross sections from exposures to northwest of map

Upper member - Shale, slate, or pelitic schist interlayered with quartzite and limestone (or marble)

Middle member-Shale, slate, or pelitic schist; lower part contains some orange-weathering calcareous layers; shown only on cross sections

Lower member-Mainly shale, slate, or pelitic schist; lower part contains layers of limestone (or marble) and pebbly quartzite; shown only on cross sections

Kingston Peak Formation (Mesoproterozoic) - Conglomerate and pelitic schist; the uppermost formation of the Pahrump Group; shown only on cross sections 


\section{References Cited}

Anderson, E.R., 2001, Structures recording synextensional shortening along and near the boundary between the Basin and Range and Colorado Plateau between Salina, Utah and Lake Mead, Nevada, in Erskine, M.C., Faulds, J.E., Bartley, J.M., and Rowley, P.D., eds., The Geologic Transition, High Plateaus to Great Basin: A symposium and field guide: The Mackin Volume: Salt Lake City, Utah Geological Association, Publication 30, 430 p. (also Publication GB 78, Pacific Section, AAPG).

Applegate, J.D.R., Jr., and Hodges, K.V., 1995, Mesozoic and Cenozoic extension recorded by metamorphic rocks in the Funeral Mountains: Geological Society of America Bulletin, v. 107 , p. $1063-1076$.

Barnes, Harley, and Poole, F.G., 1968, Regional thrust-fault system in Nevada Test Site and vicinity, in Eckel, E.B., ed., Nevada Test Site: Geological Society of America Memoir 110, p. 233-238.

Blakely, R.J., Jachens, R.C., Calzia, J.P., and Langenheim, V.E., 1999, Cenozoic basins of the Death Valley extended terrane as reflected in regional-scale gravity anomalies, in Wright, L.A., and Troxel, B.W., eds., Cenozoic Basins of the Death Valley Region: Boulder, Colo., Geological Society of America Special Paper 333, p. 1-16.

Bredehoeft, J.D., Fridrich, C.J., and King, M.J., 2005, The lower carbonate aquifer as a barrier to radionuclide transport: Waste Management Conference Proceedings, February 27 to March 3, 2005, Tucson, Arizona, 14 p.

Bredehoeft, J.D., Fridrich, C.J., and King, M.J., 2008, Groundwater flow under the Funeral Mountains, Death Valley National Park: 2008 High-Level Nuclear Waste Conference Proceedings, Las Vegas, Nevada.

Cemen, Ibrahim, 1983, Stratigraphy, geochronology, and structure of selected areas of the northern Death Valley region, eastern California-western Nevada, and implications concerning Cenozoic tectonics in the region: University Park, Pennsylvania State University, Ph.D. dissertation, 235 p., 7 plates.

Cemen, Ibrahim, Wright, L.A., and Prave, A.R., 1999, Stratigraphy and tectonic implications of the latest Oligocene and early Miocene sedimentary succession, southernmost Funeral Mountains, Death Valley region, California, in Wright, L.A., and Troxel, B.W., eds., Cenozoic Basins of the Death Valley Region: Boulder, Colo., Geological Society of America Special Paper 333, p. 65-86.

Fridrich, C.J., and Thompson, R.A., 2011, Cenozoic tectonic reorganizations of the Death Valley region, southeast California and southwest Nevada: U.S. Geological Survey Professional Paper 1783, 36 p., 1 plate.
Hamilton, W.B., 1988, Detachment faulting in the Death Valley region, California and Nevada, in Carr, M.D., and Yount, J.C., eds., Geologic and hydrologic investigations of a potential nuclear waste disposal site at Yucca Mountain, Nevada: U.S. Geological Survey Bulletin 1790, p. 51-85.

Hoisch, T.D., Heizler, M.T., and Zartman, R.E., 1997, Timing of detachment faulting in the Bullfrog Hills and Bare Mountain area, southwest Nevada: Inferences from ${ }^{40} \mathrm{Ar} /{ }^{39} \mathrm{Ar}$, $\mathrm{K}-\mathrm{Ar}, \mathrm{U}-\mathrm{Pb}$, and fission-track thermochronology: Journal of Geophysical Research, v. 102, no. B2, p. 2815-2833.

Hoisch, T.D., and Simpson, Carol, 1993, Rise and tilt of metamorphic rocks in the lower plate of a detachment fault in the Funeral Mountains, Death Valley, California: Journal of Geophysical Research, v. 98, p. 6805-6827.

Holm, D.K., Snow, J.K., and Lux, D.R., 1992, Thermal and barometric constraints on the intrusive and unroofing history of the Black Mountains: Implications for timing, initial dip, and kinematics of detachment faulting in the Death Valley region, California: Tectonics, v. 11, no. 3, p. 507-522.

Hunt, C.B., and Robinson, T.W., 1960, Possible interbasin circulation of ground water in the southern part of the Great Basin: U.S. Geological Survey Professional Paper 400-B, p. B273-B274.

Knott, J.R, Machette, M.N., Klinger, R.E., Sarna-Wojcicki, A.M, Liddicoat, J.C., Tinsley, III, J.C., David, B.T., and Ebbs, V.M., 2008, Reconstructing late Pliocene to middle Pleistocene Death Valley lakes and river systems as a test of pupfish (Cyprinodontidae) dispersal hypotheses, in Reheis, M.C., Hershler, Robert, and Miller, D.M., eds., Late Cenozoic drainage history of the southwestern Great Basin and lower Colorado River region: geologic and biotic perspectives: Boulder, Colo., Geological Society of America Special Paper 439, p. 1-26.

Labotka, T.C., 1980, Petrology of a medium-pressure regional metamorphic terrane, Funeral Mountains, California: American Mineralogist, v. 65, p. 670-689.

Link, P.K., Christie-Blick, Nicholas, Devlin, W.J., Elston, D.P., Horodyski, R.J., Levy, M.E., Miller, J.M.G., Pearson, R.C., Prave, A.K., Stewart, J.H., Winston, Don, Wright, L.A., and Wrucke, C.T., 1993, Middle and late Proterozoic stratified rocks of the western United States Cordillera, Colorado Plateau, and Basin and Range province, in Reed, J.C., Jr., Bickford, M.E., Houston, R.S., Link, P.K., Rankin, D.W., Sims, P.K., Van Schmus, W.R., eds., Precambrian: Conterminous U.S.: Boulder, Colo., Geological Society of America, Geology of North America, v. C-2, p. 463-595. 
Machette, M.N., Johnson, M.L., and Slate, J.L., eds., 2001, Quaternary and late Pliocene geology of the Death Valley region: Recent observations on tectonics, stratigraphy, and lake cycles: Guidebook for the 2001 Pacific Cell —Friends of the Pleistocene Field Trip, U.S. Geological Survey OpenFile Report 01-51, 246 p.

McAllister, J.F., 1970, Geology of the Furnace Creek borate area, Death Valley, Inyo County, California: California Department of Conservation, Division of Mines and Geology, Map Sheet 14, scale 1:24,000, 9 p.

McAllister, J.F., 1971, Preliminary geologic map of the Funeral Mountains in the Ryan quadrangle, Death Valley region, Inyo County, California: U.S. Geological Survey Open-File Report 71-187, scale 1:31,680.

McAllister, J.F., 1973, Geologic map and sections of the Amargosa Valley borate area-southeast continuation of the Furnace Creek area, Inyo County, California: U.S. Geological Survey Miscellaneous Geologic Investigation Map I-782, scale 1:24,000.

McAllister, J.F., 1974, Silurian, Devonian, and Mississippian formations of the Funeral Mountains in the Ryan quadrangle, Death Valley region, California: U.S. Geological Survey Bulletin 1386, 35 p., 3 plates.

Monsen, S.A., Carr, M.D., Reheis, M.C., and Orkild, P.P., 1992, Geologic map of Bare Mountain, Nye County, Nevada: U.S. Geological Survey Map I-2201, scale $1: 24,000$.

Niemi, N.A., 2002, Extensional tectonics in the Basin and Range Province and the geology of the Grapevine Mountains, Death Valley region, California and Nevada: Pasadena, California Institute of Technology, Ph.D. dissertation, 344 p., 1 plate, scale 1:50,000.

Paces, J.B., Whelan, J.F., Forester, R.M., Bradbury, J.P., Marshall, B.D., and Mahan, S.A., 1997, Summary of discharge deposits in the Amargosa Valley: U.S. Geological Survey Administrative Report SPC333M4 to the U.S. Department of Energy_Yucca Mountain Project.

Reynolds, M.W., 1969, Stratigraphy and structural geology of the Titus and Titanothere Canyons area, Death Valley, California: Berkeley, University of California, Ph.D. dissertation, $310 \mathrm{p}$.

Slate, J.L., and Berry, M.E., 1999, Preliminary surficial geologic map of the Beatty $30 \times 60$ minute quadrangle, Nevada-California, in Slate, J.L., ed., Proceedings of conference on status of geologic research and mapping in Death Valley National Park, Las Vegas, Nevada, April 9-11, 1999: U.S. Geological Survey Open-File Report 99-153, p. $78-80$.
Slate, J.L., Berry, M.E., and Menges, C.M., 2009, Surficial geologic map of the Death Valley Junction 30' x 60' quadrangle, California and Nevada: U.S. Geological Survey Scientific Investigations Map 3013, scale 1:100,000.

Snow, J.K., 1992, Large-magnitude Permian shortening and continental-margin tectonics in the southern Cordillera: Geological Society of America Bulletin, v. 104, p. 80-105.

Snow, J.K., and Lux, D.R., 1999, Tectono-sequence stratigraphy of Tertiary rocks in the Cottonwood Mountains and northern Death Valley area, California and Nevada, in Wright, L.A., and Troxel, B.W., eds., Cenozoic Basins of the Death Valley Region: Boulder, Colo., Geological Society of America Special Paper 333, p. 17-64.

Steinkampf, W.C., and Werrell, W.L., 2001, Ground-water flow to Death Valley, as inferred from the chemistry and geohydrology of selected springs in Death Valley National Park, California and Nevada: U.S. Geological Survey Water-Resources Investigation Report 98-4114, 37 p.

Stewart, J.H., 1970, Upper Precambrian and lower Cambrian strata in the southern Great Basin, California and Nevada: U.S. Geological Survey Professional Paper 620, 206 p.

Stewart, J.H., 1983, Extensional tectonics in the Death Valley area, California: Transport of the Panamint Range structural block $80 \mathrm{~km}$ northwestward: Geology, v. 11, no. 3, p. $153-157$.

Stewart, J.H., 1988, Tectonics of the Walker Lane belt, western Great Basin-Mesozoic and Tertiary deformation in a zone of shear, in Ernst, W.G., ed., Metamorphism and crustal evolution of the western United States, Rubey Vol. VII; Englewood Cliffs, New Jersey, Prentice-Hall, p. 683-713.

Stewart, J.H., and Poole, F.G., 1974, Lower Paleozoic and uppermost Precambrian Cordilleran miogeocline, Great Basin, western United States, in Dickinson, W.R., ed., Tectonics and Sedimentation: Soc. Econ. Paleontologists and Mineralogists Spec. Pub. 22, p. 28-57.

Stock, Chester, and Bode, F.D., 1935, Occurrence of lower Oligocene mammal-bearing beds near Death Valley, California: National Academy of Sciences Proceedings, v. 21, p. 571-579.

Sweetkind, D.S., Dickerson, R.P., Blakely, R.J., and Denning, P.D., 2001, Interpretive geologic cross sections for the Death Valley regional flow system and surrounding areas, Nevada and California: U.S. Geological Survey Miscellaneous Field Studies Map MF-2370, 32 p.

Winograd, I.J., 1962, Interbasin movement of ground water at the Nevada Test Site, Nevada: U.S. Geological Survey Professional Paper 450C, p. C108-C111. 
Winograd, I.J. and Thordarson, William, 1975, Hydrogeologic and hydrogeochemical framework, south-central Great Basin, Nevada-California, with special reference to the Nevada Test Site: U.S. Geological Survey Professional Paper 712-C, $125 \mathrm{p}$.

Wright, L.A., Greene, R.C., Cemen, Ibrahim, Johnson, F.C., and Prave, A.R., 1999, Tectonostratigraphic development of the Miocene-Pliocene Furnace Creek basin and related features, Death Valley region, California, in Wright, L.A. and Troxel, B.W., eds., Cenozoic Basins of the Death Valley Region, Boulder, Colo., Geological Society of America Special Paper 333, p. 87-114.

Wright, L.A., Thompson, R.A., Troxel, B.W., Pavlis, T.L., DeWitt, E.H., Otton, J.K., Ellis, M.A., Miller, M.G., and Serpa, L.F., 1991, Cenozoic magmatic and tectonic evolution of the east-central Death Valley region, California, in Walander, M.J., and Hanan, B.B., eds., Geological excursions in southern California and Mexico: Boulder, Colo., Geological Society of America Guidebook, 1991 Annual Meeting, San Diego, Calif., p. 93-127.

Wright, L.A. and Troxel, B.W., 1993, Geologic map of the central and northern Funeral Mountains and adjacent areas, Death Valley region, southern California: U.S. Geological Survey Miscellaneous Investigation Series Map I-2305, scale $1: 48,000$.

Publishing support provided by:

Denver Publishing Service Center

For more information concerning this publication, contact:

Center Director, USGS Geosciences and Environmental Change

Science Center

Box 25046, Mail Stop 980

Denver, CO 80225

(303) 236-5344

Or visit the Geosciences and Environmental Change Science Center Web site at: http://gec.cr.usgs.gov/ 
